\title{
الجانب السياسي في شعر معروف الرصافي
}

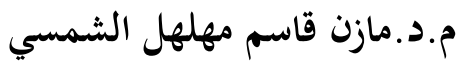

جامعة بغداد/ مركز إحياء التراث العلمي العربي

\section{MKasm922@gmail.com}

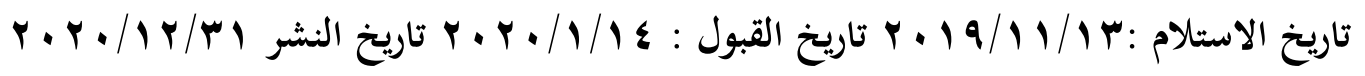

الملخص:

عاش الشاعر معروف الرصافي في حقبة قلقة من تاريخنا الفكري أواخر القرن الثاسع عشر والنصف

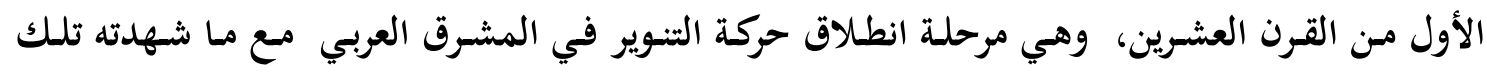

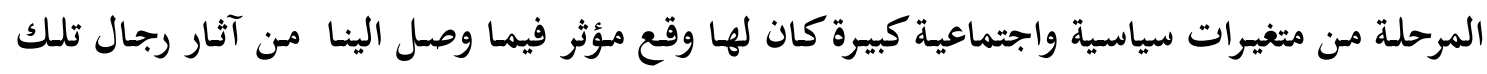

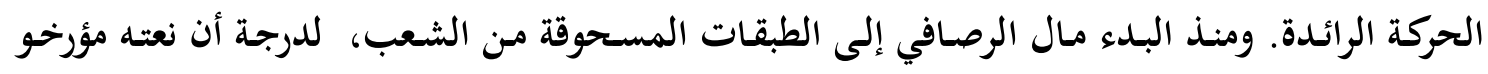

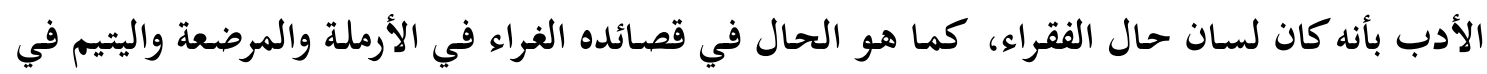

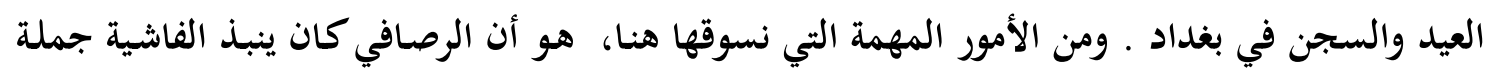

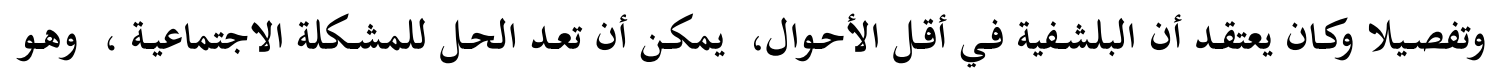

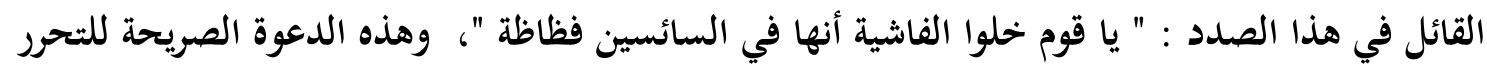

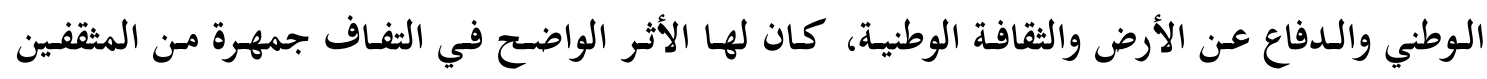

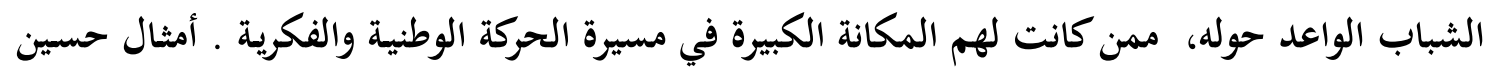

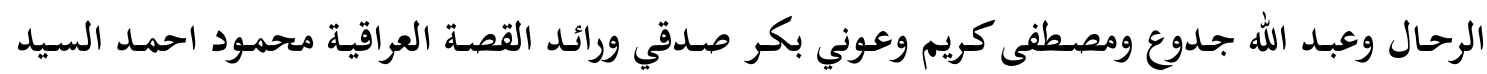
وغيرهم.

ومن جانب آخر، فقد تجسدت وطنيته في معارضته معاهدة عام ـ ب ا التي عقدت بين بريطانيا

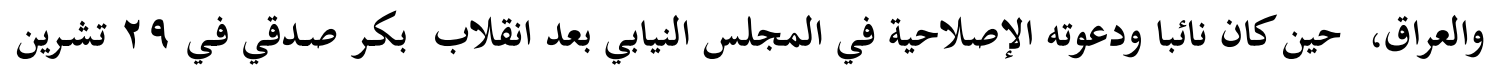

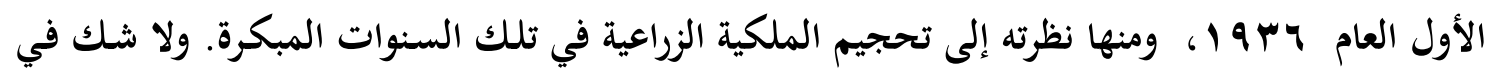

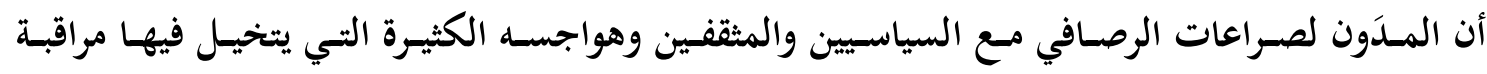

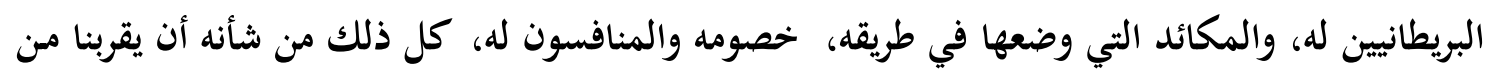

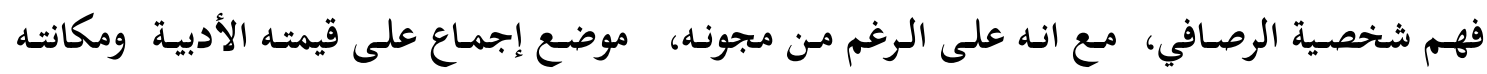

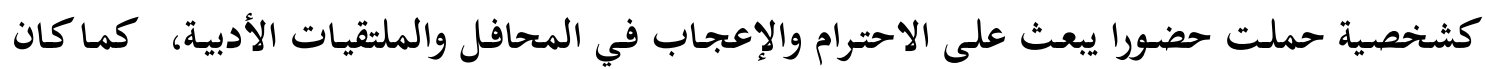
مترفعا عن الدخول في الصراعات الافتعالية.

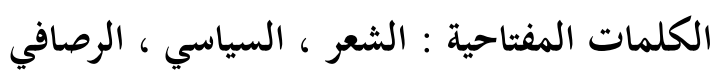




\title{
The political side in Al-Resafi poetry
}

\author{
Mazin Qasim Muhalhal \\ Center of revival heritage \\ Baghdad university
}

\section{Abstract:}

The poet Maarouf Al-Rusafi lived in an anxious era of our intellectual history at the end of the nineteenth and first half of the twentieth century, which is the stage of the launch of the Enlightenment movement in the Arab East with the great political and social changes that witnessed this stage that had an influential impact on the effects of the men of that movement. Leading. From the beginning, al-Rusafi tended to the crushed classes of the people, to the point that historians of literature called him the mouthpiece of the poor, as was the case with his glorious poems in the widow, the nursing woman, and the orphan in the feast and prison in Baghdad. Among the important things that we cite here, is that Al-Rusafi was rejecting fascism altogether and in detail and believed that Bolshevism in the least cases could prepare the solution to the social problem, and he said in this regard: "O people, let Fascism be in terms of those who are oppressive", and this frank call For national liberation and the defense of the land and national culture, it had a clear impact in wrapping a crowd of promising young intellectuals around it, who had a great position in the path of the national and intellectual movement. The likes of Hussein AlRahal, Abdullah Jadou, Mustafa Karim, Awni Bakr Sidqi, and the pioneer of the Iraqi story, Mahmoud Ahmed Al-Sayed and others.

On the other hand, his patriotism was embodied in his opposition to the 1930 treaty that was concluded between Britain and Iraq, when he was a deputy and his reformist call in the House of Representatives after the coup of Bakr Sidqi on October 29, 1936, including his view of limiting agricultural property in those early years. There is no doubt that the blogger Al-Rusafi's conflicts with politicians and intellectuals and his many concerns in which he imagines the British observing him, and the intrigues that he put in his way, his opponents and rivals to him, all of this would bring us closer to the understanding of Al-Rusafi's personality, although in spite of his content, there is consensus on His literary value and his status as a figure carried a respectable and impressive presence in literary forums and forums, as he was refraining from engaging in fraudulent conflicts.

Key words :poetry,political ,Al-Resafi 
إن إنسانا مثل معروف عبد الغني الرَّصافي الثـاعر المفكر المجادل المشكك المتمرد المعاند، لا يجمـع تمـرده وجدله بحـث ولا يبلـغ سيرته كاتـب، فهو إثـكالي في حياته وفكـره بــأ معتمـرا العِمامـة، ومتتلمذا لعلامة أيامه محمود شكري الآلوسي ذلك الجانح صوب السلفية من دون انتماء، ربما دفعته إليها كراهة للعثمانيين، يقابله غريم تلميذه جميل صدقي الزهاوي اندفع ضد السلفية الوهابية في كتابه "الفجر الصـادق" ويحصـل أن صـاحبنا يخـالف معلمسه المانحسه لقـب الرَّصـافي، ببيتين يقرض فيـه ذلك الكتاب حيث قال:

$$
\begin{aligned}
& \text { هذا كتابِّ فيه يَّضح الهدى } \\
& \text { علناً فتسطع للعقول حقائق } \\
& \text { يا ظلمة الشبهات والكذب إنجلى } \\
& \text { فلقد بدا للحق فجر صادق }
\end{aligned}
$$

كتب الكثيرون وروى الأكثر عن معروف الرَّصافي، حتى عمرت المكتبة بمظان موضوعه، جمع رسائله الأديب الأريب الشيخ عبد الحميد الرشودي ومن تلك الرسائل، المتبادلة مع مختلف طبقات المجتمع من أصدقاء وحكام وأهل علم وأدب، تتكون لدى الباحث في غياهب هذا الرجل، ملامح شخصيته في سطور الحنو والرضـا، مثلمـا كتب إلى عبـد المسيح ثروت وإلى محمـود السـنوي، وفي سطور الجفـاء والسخط مثلما كتب إلى غريمه جميل صدقي الزهاوي ونوري السعيد، فحين يذكر اسم معروف عبد الغني الرصافي، فـأن أول ما يتبادر إلى ذهن المتلقي، انه أديب وشاعر له قصائده الشعرية التي رسمت هويته، ولن يتصور أحد باستثناء من كان مطلعا على سيرته وأخباره، انه على وفق ما أقحم بـه نفسه في شؤون السياسـة واشـكالياتها، يمكـن أن يتـراءى لبعضـهم تصـنيفه رجـل سياسـة، مثل مـا هـو رجـل أدب وشـاعر

وقد يتفق معنا بعضهم ويختلف آخرون، حين نذكر أن الرصافي لم يكن رجل السياسة والدولة بالمعنى المعروف للرجـل السياسي ولعـل صـراحته وصـدقه في القـول أبعـاه عنها، بقــر مـاكـان بمثابـة شـاعر السياسة والاجتماع، إذ عرف بهذين الجانبين من موضوعات الشعر وأغراضه في العصر الحديث ونجح فيهمـا نجاحـا كبيـرا وأطلق قصـائده صـرخات مدويـة، ألهب بهـا شعور الشـباب ونـدد بـالظلم والطغيان والاستبداد وطالب بالحد من السلطة المطلقة وشهد أخطاء السياسة واكتوى بنارها وأصابه ما أصاب غيره من الوطنيين والمخلصين · ويذهب إلى هذا الرأي بعض من عني بسيرة الرصافي ونتاجه الأدبي من أمثال 
رؤوف الواعظ، الذي كتب رسالة للماجستير، خصصت لدراسة حياة الرصافي وأدبه السياسي إذ قال ما نصه: " ان الدارسين ممن اهتموا بالجانب السياسي في قصائد الرصافي، كانوا قد فسروا الحوادث التي تصدى إليها في قصائده تفسيرا سياسيا، بل إنهم كثيرا ما بالغوا في هذا الجانب لأن الرصافي لم يكن سياسيا، بل كان شاعرا في السياسة والاجتماع "، وهذا الرأي يقول بـ أيضا الدكتور أحمد مطلوب وهو من أوائل المهتمين بأدب الرصافي، حين أشـار إلى أن الرصافي: "عالج الشعر السياسي في مختلف العهود، إلا أن شعره السياسي في كل الأدوار، لم يخـرج عـن كونه شعر مناسبة سياسية أثّرت في الرصافي فاستوحى منها قصيدة مضيفا عليها من عواطفه الخاصة الشيء الكثير من دون الالثفات إلى المقومات السياسية لتلك المناسبة "(؟).

إن هموم تلك السياسة وما كان يشهده من كوارث ومآسٍ شهدها شعبه وقتذاك، كانت تثير في نفسه ثورة الشعر، فكان الشعر عنـده تجليـا واضـحا لوضع سياسي قلق، كان هـو شـاهدا عليه، مما استوجب الخوض في غماره، إلا انه لم يرق في ذلك إلى مستوى من يعملون في ميدان السياسة، بل كان رد فعل لما آلت إليه طبيعة علاقته بالدولة، أو سلوكية الدولة ومحاولاتها إزاء احتوائه، وهذه صنعت منه رجلاً انتمى إلى عالم السياسة، على الرغم من انه لم يكن من رموز هذا العالم (ب). ويمكن القول الى جانب مـا قيل :" أن الرصـافي ترك مـ بعـد تراثاً مرموقاً جمع ع بين الادب والفكر والسياسة والعلم، ما زال بحاجـة الى الدرس والتمحيص لما ينطوي على تجارب وعبر ودروس مفيدة. والى ذلك فهو بالتالي يختلف من هذه الزاوية عن معظم الشخصيات ممن عني الباحثون بترجمتهم "((\&). ولا شك في أن ما قيل عن الرصافي من قدرة في مواجهة المسؤولين سواء في عهد الدولة العثمانية أو الملكية في العراق، كان وراء سعينا لتقصي ماكان لهذا الرجل من أثر في واقع الدولة السياسي، ولاسيما أنه رجل مخضرم، عاصر أكثر من عهد، كان يدون في قصائده أحداث ذلك العصر ويوثث تداعياته ومؤشراً أهم اشكالياته، ولاسيما إذا ما علمنا انه لم يتعاط مع رجال العهد الملكي، بما فيهم

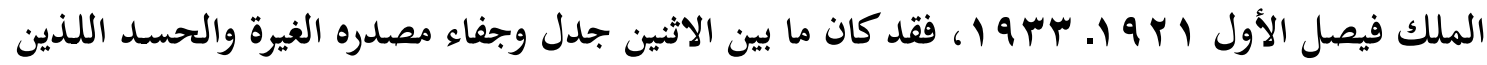
كان يكنهما الرصافي للملك فيصل، وهو ما انعكس على ملاحقة الرصافي ورصده لتعثرات الدولة وبيان مثالبها، وهذا الأمر سنجده ماثلا أيضا في علاقة الرصافي بالسياسي العراقي المخضرم نوري السعيد، إذ لاحقته أبيات شعره، كأنها حمـم كادت تقصـم ظهر الأخير لولا حنكتـه ونباهته. والى ذلك، خحاض الرصـافي غمـار الحيـاة النيابية، حين أصسبح نائبـا في مجلس المبعوثـان العثمـاني (•) لـدورة واحسدة عـام ץ ا ا 1، ولخمس مرات متتالية في مجلس النواب العراقي إبان العهد الملكي، فكان جريئا في طرحه لا 
يتوانى أن يقول لنفسه : انك خطاءة، مما ألّب عليه جراء ذلك الكثير، فعمد وهو النائب في مجلس

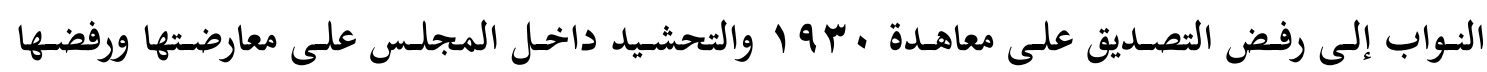
واستمر على هذا المنوال، فكان ذلك من اخطر واهم ما اعترض وتقاطع فيه مع الحكومات المتعاقبة

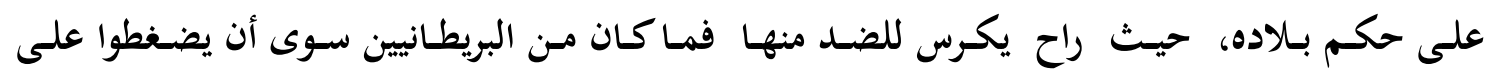

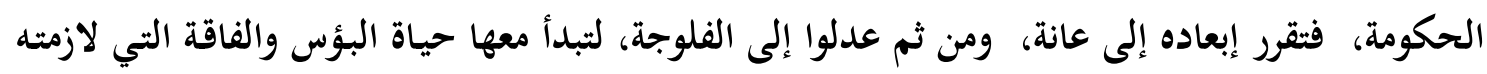

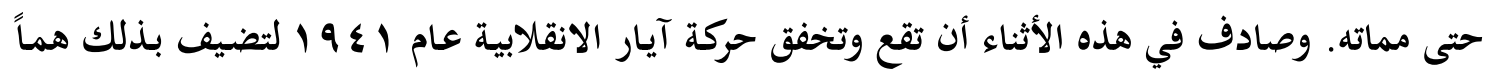
الى همه وكان فيما ترتب على هذا الإخفاق، من ظلامات بحق المناضلين والساسة الذين قادوا الحركة، هما آخر. ويعود الرصافي إلى بغداد وفي ذهنه يحمل أفكارا وعلى ظهره يحمل أسفارا، مادتها ثورة

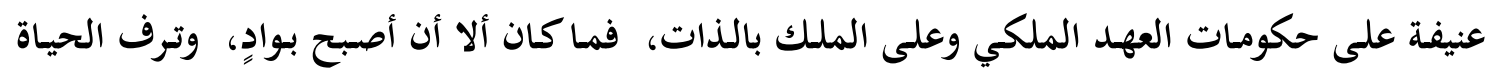
الذي كان إليه يطمح بواد. ولم نغفل في هـذه العجالة مـ دراستنا تلك أن نتطرق أيضـا لأثره في لهي الصحافة وما أدته صحيفته "الأمل"من تأثير على الساحة السياسية. ولادة الرصافي ونسبه ولمحات من سيرته كان العراق في أواخر القرن التاسع عشر وأوائل القرن العشرين تحت حكم العثمانيين، فكان الولاة يتعاقبون على حكمه وربطه بالدولة العثمانية محاولين استرضاء الباب العالي وكسب ثقة الشعب لنطول

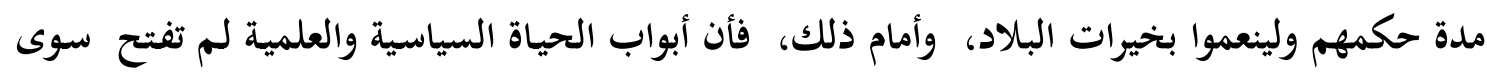
أمام قلة من أبناء البلد الأثرياء وأصحاب الجاه والنفوذ، ولم يكن من السهل اليسير أن يحكم البلاد من

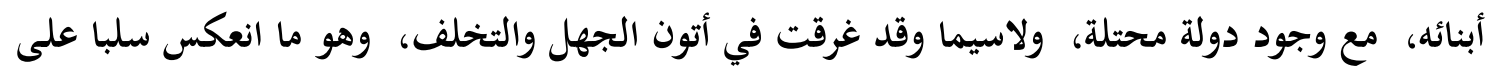
أوضاع العامة من الناس، فكانت الحياة الثقافية في وضع لا تحسد عليه، وكانت الأمراض متفشية تفتك بالناس والسعيد من استطاع أن ينجو منها ويدخل الكتّاب(")، والمدارس الحكومية ليسافر إلى الأستانة، ويعود حاملا فرمان الوظيفة أو المنصب الذي تتوق إليه النفوس، وفي مثل هذه البيئة وفي محلة من محلات بغداد القديمة، تسمى بمحلة " القراغول "، وفي ليلة شتوية طويلة قارصة البرد من أيام شهر

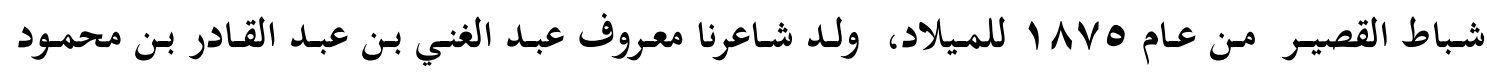
الجباري الرصافي، في عهد السلطان عبد العزيز، من أم عربية تدعى فاطمة بنت جاسم ونجود الشرَّاد

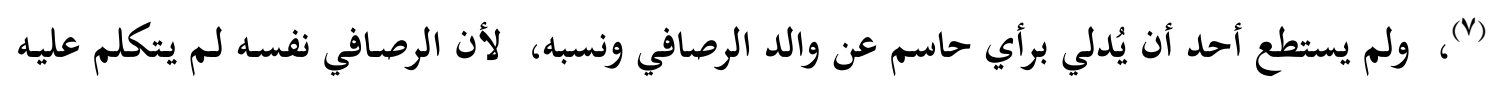

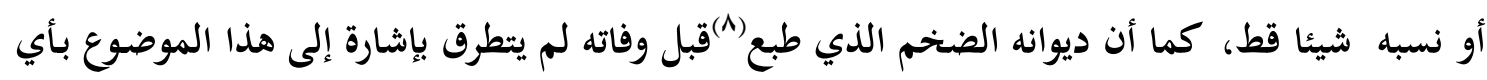


حال من الأحوال(9)، وقد يكون ذلك من باب الترفع عن التفاخر أو ذكر الأنساب معولين على ما يقدمه المرء من أعمال، تكون أثمن من النظر لما خلفه السلف من تلك الفوائد .

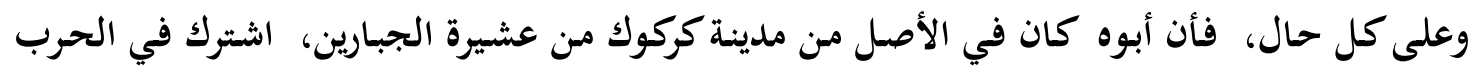

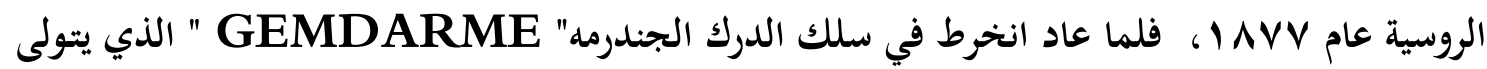
المحافظة على الأمن خارج المدن لدى الحكومة العثمانية برتبة " باش جاويش" . رئيس عرفاء ـ لذلك

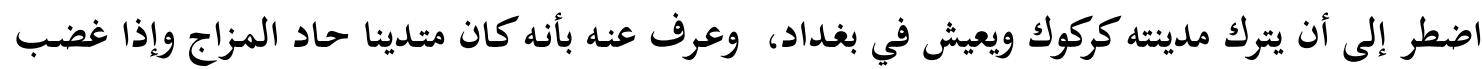
أخاف، وإذا ضرب أوجع، وكان كثير الأسفار ودائما في وظيفته مما اضعف لقاء الرصافي به إذ لم يكن يراه إلاً لماماً . ونتيجة لما كان يتصف به من ورع وإصلاح (·)، فقد التقى بشخص على شاكلته اسمه

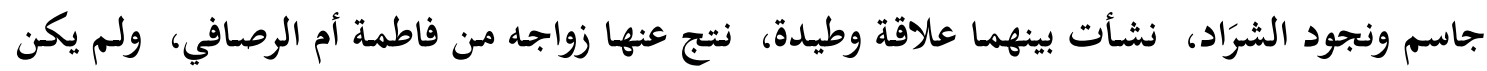
حينها يمتلك دارا يستقر هو وأسرته فيها، الأمر الذي اجبره على السكن مع والد زوجته الذي كان تاجر

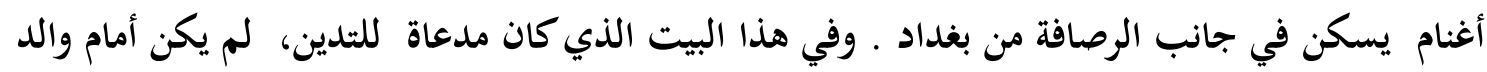

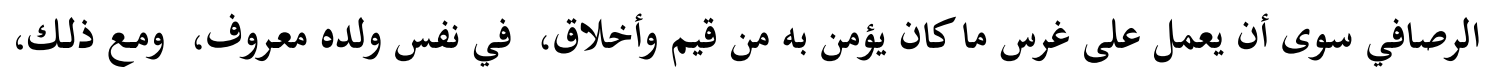

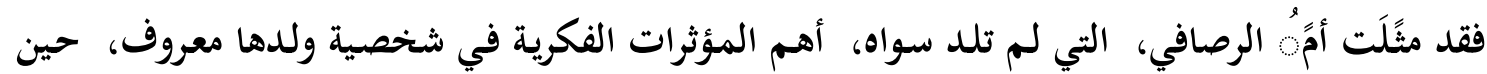

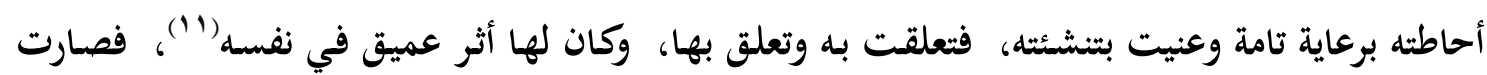
مرجعه في كل شيء، حتى بعد تجاوزه العقد الأول من حياته، وهي التي ألزمت نفسها بوجوب أن تراه

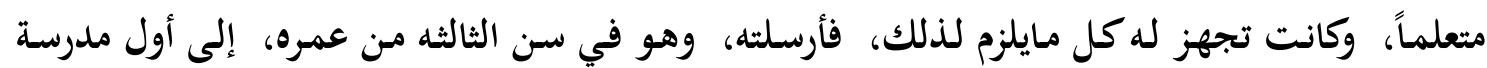
قريبة من داره، وكانت قائمة على الثدريس فيها أمرأة، انتقل بعد ذلك إلى مدرسة في الحيدرخانة تدعى بـ مدرسة الملا بايز، وفيها تعلم الحروف الهجائية بكتاب يدعى جزء يا فتاح، انتقل بعد ذلك إلى مدرسة آخرى في الميدان تعرف بـ مدرسة منيف أفندي، وفيها، راح يكب على دراسة القرآن على الملا "

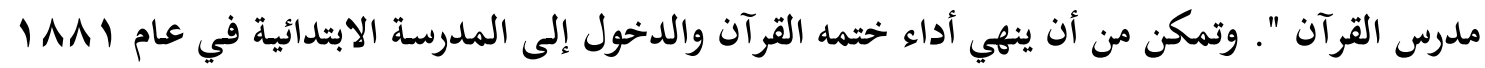
التي كانت تقع ضمن جامع فيه مدرسان ـ وبعد هذه المرحلة انتقل إلى مدرسة الرشدية العسكرية عام

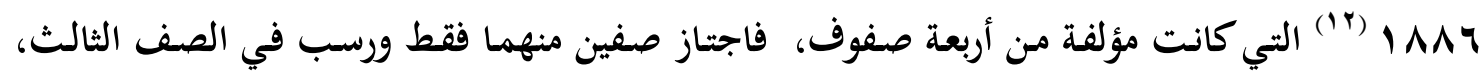
وهو ما دفعه إلى ترك هذه المدرسة مقرراً دخول المدرسة الدينية في جامع الحيدر خانه لدراسة العلوم فيها على المدرس السيد محمود شكري الالوسي، فكان أول ما درس هو كتاب " الأجرومية "("آ). وفي مسي هذا السياق، ذكر الرصافي أن الالوسي، أعجب بنبوغ تلميذه وذكائه المفرط وأبدى اهتماما خاصا به

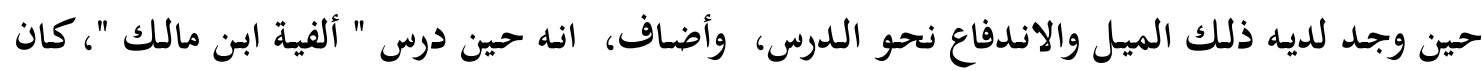


الالوسي قد طلب من احد تلامذته وكان يدعى عبد اللطيف العربي، أن يتولى تدريسه، إلا أن الأخير لم

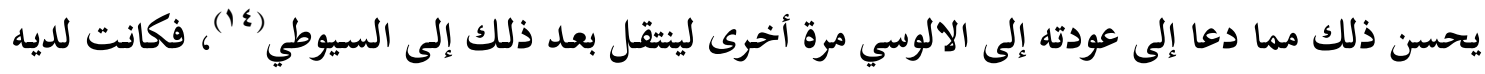

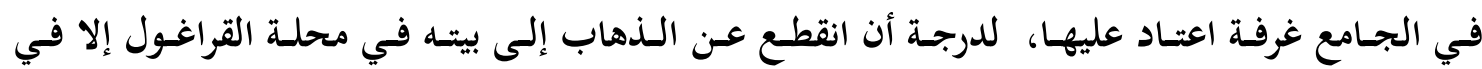
المناسبات(1)، مثل غيره من الطلبة وقد درس " المنطق " على الشيخ عبد الرحمن القرداغي في جامع بابا كركر في الرصافة ـ ودرس على المدرس عبد الوهاب النائب " مادة الفقه " في مدرسة الخاتون، و" البيان والبديع " في مدرسة الشيخ صندل في الكرخ، ودرس كتاب" مغنى اللبيب عن كتاب الاعاريب " على الشيخ عباس حلمي القصاب، واتصل الرصافي بالثيخ قاسم القيسي، من أفاضل علماء بغداد،

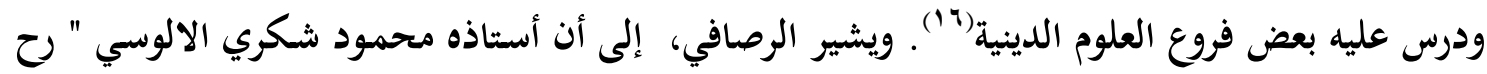

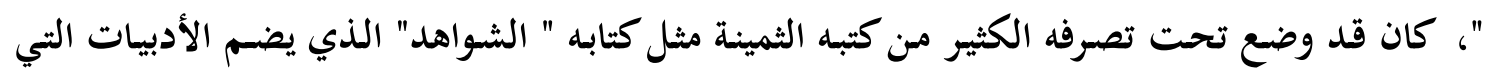
يوردها أهل الأدب شاهدا لإثبات قاعدة ما، وبسبب عشقه لهذا الكتاب وإعجابه فيه، فقدد عمد إلى حفظ أكثر من خمسة عشر ألف بيت، وكان من عادة المدرسين أن يضعوا كتاب الشواهد ليرجعوا إليه في أثناء الثدريس، إلا أن السيد محمود شكري الالوسي استغنى عن هذا الكتاب، وكان يقول لتلامذته

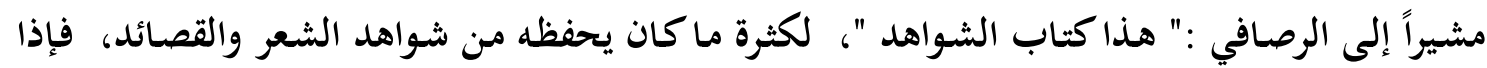

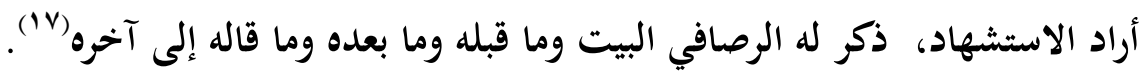

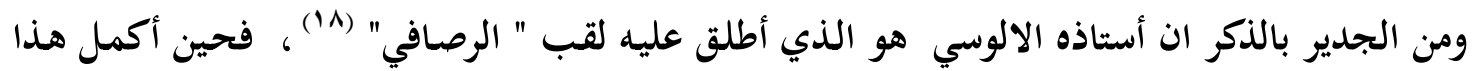

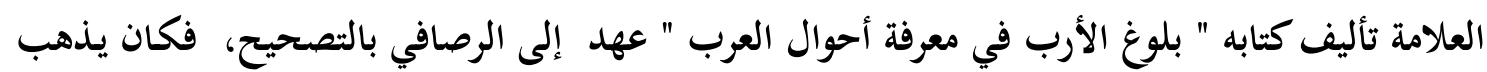
يومياً إلى المطبعة(19) لتصحيح المسودات، و وبعد أن تم الطبع، عمد الرصافي إلى تقريضه بعدة أبيات

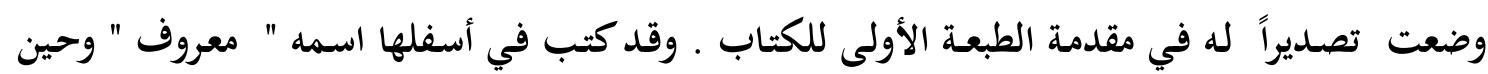
اطلع الالوسي على أبيات التقريض، أعجب بها أيما إعجاب وقال مخاطباً الرصافي :" اكتب اسمك الرصافي لأنك معروف الرصافة كما كـان الكرخي معروف الكـرخ "، ولم يوافق الرصـافي على هـذا

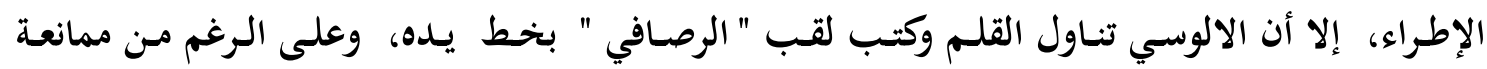

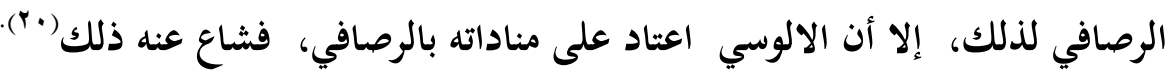
وبعد أن أنهى الرصافي دراسته التي استمرت اثنتي عشرة سنة، تم تعيينه مدرسا في منطقة الراشدية

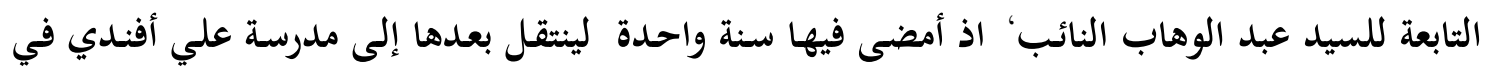

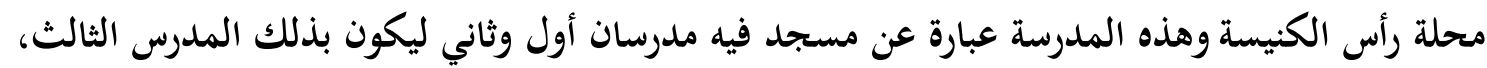
ولم يمض فيها سنة واحدة، حتى تم نقله إلى مدرسة الإعداد العسكري، مدرسا للغة العربية التي بقي 
فيها ثلاث سنوات 7 ـ 9 (199 ـ9 19، وكان من طلاب هذه المدرسة، حكمت سليمان الذي أصبح

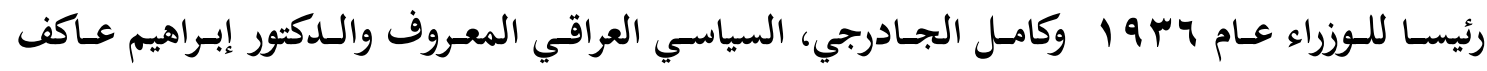
الالوسي، الذين حفظوا له تلك اليد البيضاء عليها وظلوا يذكرون تلك الأستاذية بكل تجل واحترام .

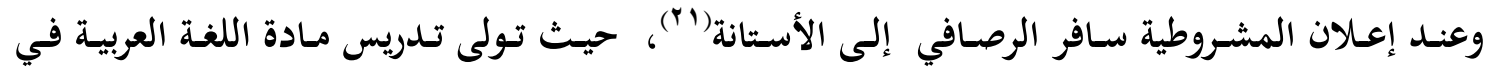

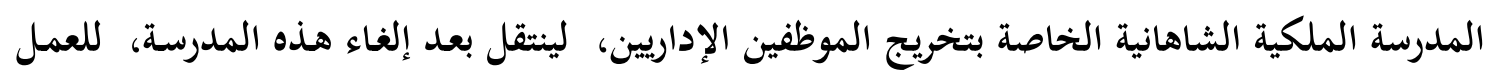

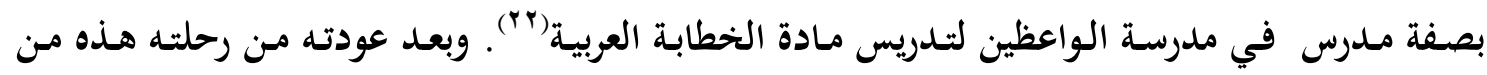

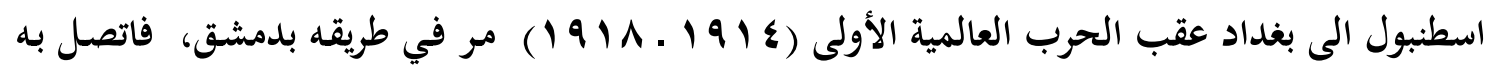
احسد المعنيين بالتربيـة والتعليم في فلسطين، وعرض عليها مهمة تـدريس آداب اللغـة العربية في دار

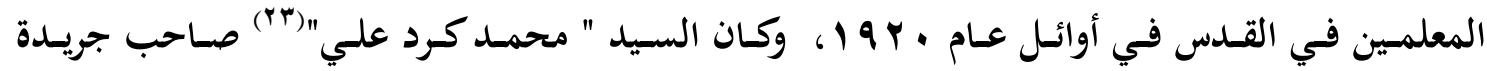
المقتبس، الذي رشـح الرصافي لعضـوية المجمع العلمي العربي بدمشـق، المفـاوض لهـذا العقدـ بين الطرفين، وحين ذاك سافر الرصافي إلى القدس، وبدأ بتدريس هذه المادة براتب خمسة وعشرين جنيها مصريا مع تكاليف الأكل والمنام. ويؤكد الرصافي في مذكراته، انه وبعد رجوعه من القدس إلى بغداد، نزل في بيت كان له فيه ذكريات مع والدته، التي كانت قد توفيت في غيابه، وهو ما البسه ثوب الكآبة دوما، والذي اجبره على معاقرة الخمر فيما بعد .كما يذكر . ويقول أن أعمامه في تلك المدة ، كانوا قد اعتادوا على زيارته، وهو بدوره ما فتئ يبادرهم الزيارة، إلا انه لم يكن يفهم منهم شيئا لأنهم يتكلمون اللغة الكردية ـ ويقول إنَ ذلك

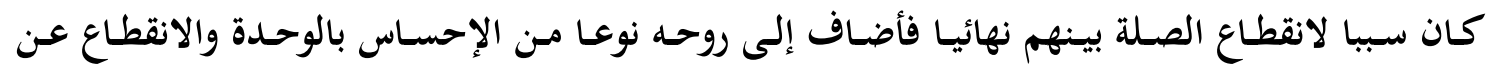

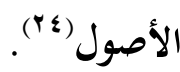
أما عن حالته الاجتماعية فقد تزوج من امرأة تركية في الاستانه اسمها بلقيس، وبسبب سوء حالته المعاشية هناك، فقد غادرها إلى القدس، واستقر فيها لحين من الزمن، ليعود مرة أخرى إلى العراق. وبسبب هذه التنقلات مع تزايد عوزه وفاقته، طال فراقه عن زوجته، التي ما فتئت تتوسل به للعودة إليها.

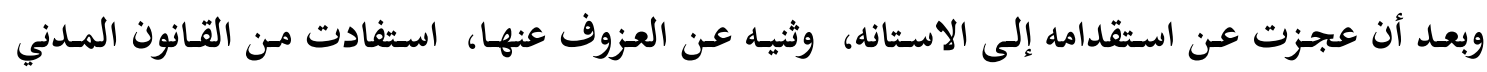

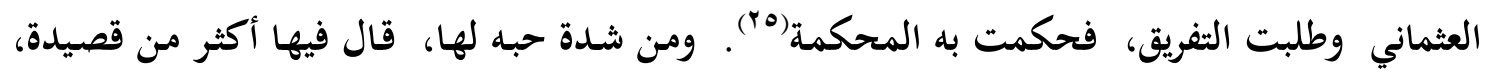

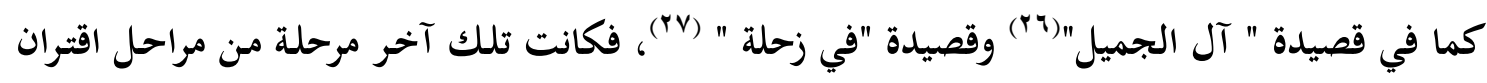
الرصافي بامرأة، كان يعشقها عشقا خفيا، لطالما كشف عنه في أبيات من شعره، إلا انه كان يأنف من البوح به، وذلك على ما يبدو كان قد أضفى على شخصيته شيئا من التمرد على الواقع الذي لم يُبق له 
ما يندم على فقده، من دون الالتفات الى عواقب ما سيُقدم عليه، فكان سبباً انعكس على آلية تعاطيه مع الواقع الذي كان يعيشه، سواء في مجال السياسة، أو فيما يتعلق بعلاقاته الاجتماعية. وفي هذا السياق من ذكر أسباب تمرده على الواقع، أشار الرصافي الى انه عقب الانقلاب العثماني الذي نفذه الاتحاديون عام ^ • 9 |(^^)، كان في دمشق يرتدي العمامة والجبة والزبون، وهي رمز لرجال الدين، حيث كانت الشرطة تطارد كل من يرتدي العمامة، وبسبب البرد ارتدى فوق الجبة عباءة صفراء، وفي هذه الأثناء، لمحه صاحب المقهى بهذا الزي، مما ولد لديه ردة فعل كبيرة، وألح عليه بالتخلص من العمامـة وإلا سيسبب له كارثة. فترك الرصافي المقهى وسار إلى جانب الطريق قرب مقهى الباب العالي في دمشق، فأحاط بـه الجند من كل جانب وهم ينادوه يا عدو الله. وما هي إلا لحظات حتى وجد نفسه تحت تحقيق تمكن من الإفلات منه، إذ تركوه لحاله ليدخل مقهى آخر حيث وجـد فيه صــيقا قـديما اسـمه عمـر فخـر الـدين الـذي أثــار عليـه بضـرورة الـتخلص مـن هـذا الـزي بالسـرعة الممكنة(9 (). فكانت تلك اللحظات بمثابة هزة عنيفة، أيقظت في دواخله وأعلمته أن ما بناه في الماضي القريب، وما اعتاد عليه من حياة التدين والتمسك بالقيم والمبادئ، لم يكن قد جاء على أساس رصين، بقدر ما كان خضوعا لبيئة ذات جو ديني، متزمت ما لبث أن انقلبت موازينه بمجرد أن تبدل فيه ظرف المكان والزمان، فكانت تلك الحادثة آخر ما جمعته وهذا الزي الديني الذي فارقه الى الأبد، إذ اعتـاد لبس البنطلون والطربـوش ليكون ذلك انعطافـا خطيـرا في شخصسيته، عندما تغيرت معها نظرتسه للحياة، بل توسم مع هذا التغيير، سبلاً ووسائل كانت بشكل أو بآخر قد ألبسته جسـا وروحا مغايرين تماما لما كان عليه بالأمس، وإذا كان شبيه الشيء منجذب إليه، فلا بـد من الإشـارة إلى أنه كان على علاقة بالثاعر جميل صدقي الزهاوي، الذي كان يرتدي العمامة أيضا، وحين خحاف أن يتعرض له رجال الشرطة عمد إلى الهرب مع احد البغداديين واسمه " صالح الملي" (•") وهو أيضا من المعممين، ووصلا إلى محلة " بيك أو غلي "(آ") وهناك اخفيا نفسيهما في بيت أسرة مسيحية خحلال مدة المحنة، وكان الزهاوي يرتدي سترة وبنطلونا ومعطفا طويلا إلى حد الركبة ويلبس في رأسه عمامة وإذا أراد أن يرتكب المعاصي، يرفع العمامة ويضعها في جيب المعطف فيصبح أفنديا من دون أن يلحظه احد . ويذكر أن هذا الرجل كان قد نزع العمامة بعد الانقلاب ولم يعد إليها أبدا(rّ). وقد وجد في شاعرنا الرصافي غريما وخليلا في آن واحد. وأمام هذه المتغيرات في حياة الرصافي، يكون قد استقر في منزل يقع في منطقة سوق الهرج قرب الميدان في الزقاق المؤدي إلى المدرسة الثانوية المركزية في بغداد(بس). 
ومن كل ذلك ولربما أشياء أخرى لم نقع عليها، يتبين أن الرصافي قد نشأ في مجتمع ورث من كوارث الماضي الكثير، واستقرت فيه رواسب الحكم الفاسد من عهد طويل، وكان كل ما فيه يدعو المفكر الحر الذي صنعته الظروف من أمثاله إلى التمرد على واقعه المعاش. وإذا ما علمنا أن المرء هو ابن الظرف الذي يعيشه، فقد نشأ الرصافي في بغداد، وكان العراق جزءً من السلطة العثمانية، رأى كيف كان الولاة العثمانيون يتعاملون مع الشعب، الذي بدا لا حول له ولا قوة أمام قوة تعيش كأنها في لئي

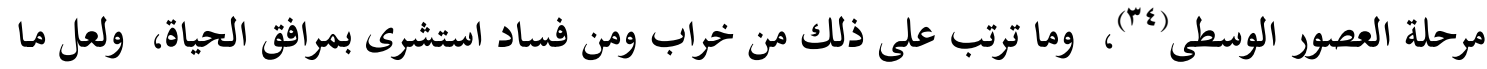

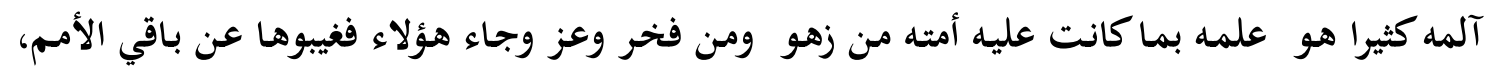
وكل ذلك خلق في داخله ثورة لم تهدأ، حتى فارق الحياة، وهو غير راضٍ عنها، فكتب ماكتب ولعل

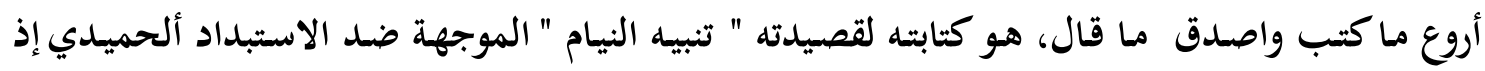

جاء فيها:

$$
\begin{aligned}
& \text { أما آن أن يغشى البلاد سعودها ويذهب عن هذي النيام هجودها } \\
& \text { متى يتأتى في القلوب انتباهها فينجاب عنها رينها وجمودها }
\end{aligned}
$$

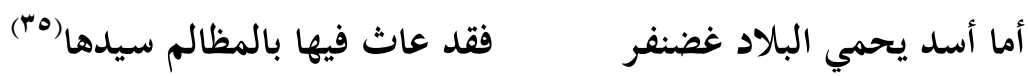

لقد بدأ الرصافي بكتابة الشعر، منذ أن بلغ السادسة عشر من عمره("ج)، وهو يشهد معاناة أبناء

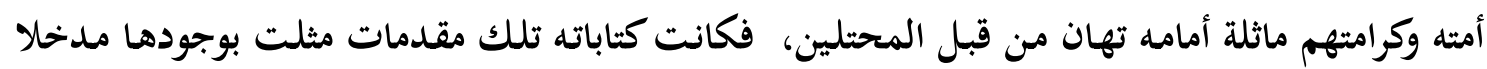
لعالم السياسة على قدر ما أناخ به الحمل وقتذاك، بوصفه شاهدا على تداعياتها في بلاده ـ وللحقيقة نقول، لو قرأنا شعر الرصافي بروية وبتعمق، فسرعان ما سنتعرف إلى أن تاريخ العراق منذ عهده الملكي،

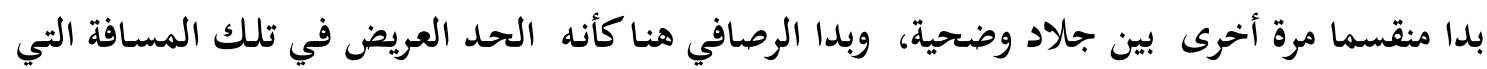
لا يمكن معها إعادة اللُحمة للمشطور من التاريخ في صيغته الجديدة . الرصافي في عهد الدولة العثمانية لقد بدأ الرصافي منذ عام 1ه 1 1 نقده اللاذع للاستبداد ألحميدي، داعيا العرب إلى الكفاح ضده فكان ذلك بداية طريقه السياسي والذي سرعان ما استهدف بـه أبناء جلدته، حين وصفهم بقصيدته الرائعة " تنبيه النيام "(V)"، حيث ابدى فيها عجبه لقوم يخضعون لدولة، يسوسهم بالموبقات عميدها. كذلك فأن الرصافي، بلغ أقصى ما بلغه أي مثقف عراقي في تلك المرحلة حين بشر وطالب بالنظام الجمهوري في قصيدته " رقية الصريع " التي جاء فيها : إن الحكومة وهي جمهورية كثفت عماية قلب كل مظلل 
وأغلب الظن، أن تطرف الرصافي بالقياس إلى زمانه، هو الذي دفع جريدة " المناظر" التي كانت

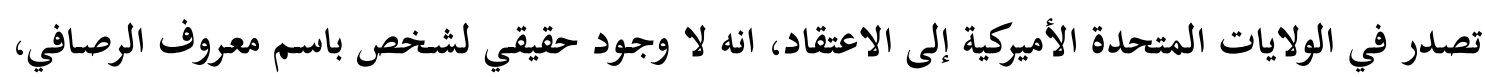

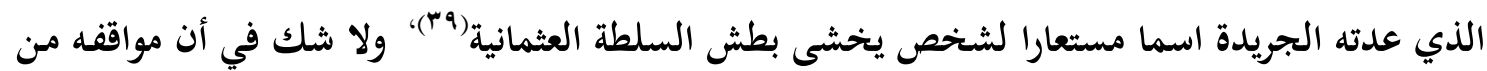

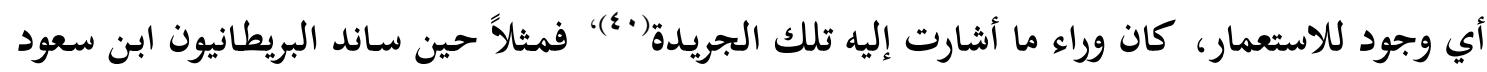
في قتاله ابن الرشيد في عام ع ـ 9 1، الذي كان مع العثمانيين ضدهم، رأى الرصافي أن ما نتج عن هذه المواجهة بمثابة نكسة لأبناء بلده، وشههد ما عاناه الجند العثمانيون من جراء تلك المعركة، فيدعا في قصيدته المعروفة بـ "إيقاظ الرقود" إلى مقارعة الاحتلال البريطاني، ما لبثت تلك القصيدة أن انتشرت في العراق بسرعة عقب تلك النكبة حيث جاء فيها :

$$
\begin{aligned}
& \text { إلى كم أنت تهتف بالنشيــد وقد أعياك إيقاظ الرقود } \\
& \text { فلست وان شددت عرا القصيد بمجد في نشيدك أو مفيد } \\
& \text { لان القوم في غي بعيد } \\
& \text { وان أنهضتهم قعدوا وئادا }
\end{aligned}
$$

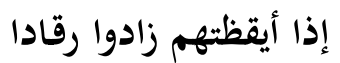

$$
\begin{aligned}
& \text { كأن القوم قد خلقوا جمادا } \\
& \text { فسبحان الذي خلق العبادا } \\
& \text { وهل يخلو الجماد عن الجمود (1) }
\end{aligned}
$$

والى ذلك دعا الرصافي، جميع العرب إلى الانضمام إلى جمعية الإصلاح في ولاية بيروت، والمطالبة بإصلاح الأوضاع في ولايتهم، وانتهاز الفرصة لتحقيق وطنيتهم، وبهذا الخصوص، انشد قصيدته الرائعة " في معرض السيف " والتي جاء فيها :

$$
\begin{aligned}
& \text { ما بالهم لم يفيقوا من عمايتهم وقد تبلج أصباح المنى لهم }
\end{aligned}
$$

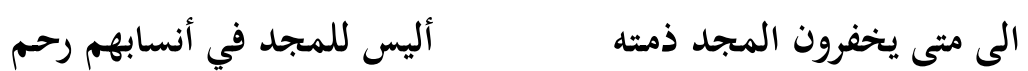

$$
\begin{aligned}
& \text { ومن يعش وهو مضياع لفرصته ذاق الثقاء وأدمى كفه الندم } \\
& \text { وكل من يدعي في المجد سابقة وعاش غير مجيد، فهو متهم (rاء) }
\end{aligned}
$$

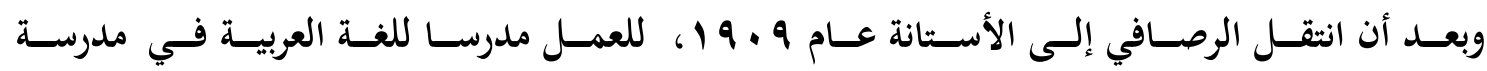
الواعظين ("آ)ُوقف عن كثب على أحوال السلطنة العثمانية في عاصمة الخلافة وعلى الثيارات السياسية والحزبية التي كانت تصطرع فيها، ولاحظ مدى التفسخخ الذي بلغت إليه السياسة وإدارة الإمبراطورية المتداعية ورأى أيضا كيف كانت تباع المناصب وتشترى، وكيف يتم اختيار الولاة والقضاة، وكيف 
كانت تتحكم الأهواء في مصائر الناس وتعبث المكائد في التقريب والتبعيد والحظوة والتشريد، وعرف ما هو نهجهم في سياسة التتريك والنظر إلى الأقاليم التابعة التي سادت فيها الفتن، و أطبق عليها الجهل والمرض، كأدوات للاستخدام تجبى أموالها لبناء القصور للسلاطين (؛ ؛). كل ذلك على على ما يبدو، زاد في ثورة شاعرنا على الحكم العثماني فرفع عقيرته في طلب الإصلاح وتغيير الحال ورد الحقوق

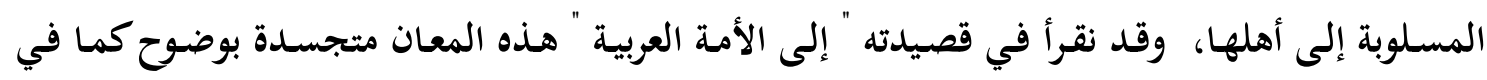

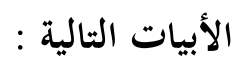

$$
\begin{aligned}
& \text { نظرت إلى عرض البلاد وطولها فما راقني عرض هناك وطول } \\
& \text { ولم تبد لي فيها معاهد عزها ولكن رسوم رثة وطلول } \\
& \text { أقول لقومي قول حيران جازع تهيج به أشجانه فيقول }
\end{aligned}
$$

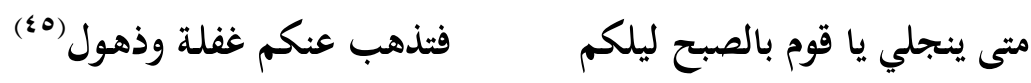

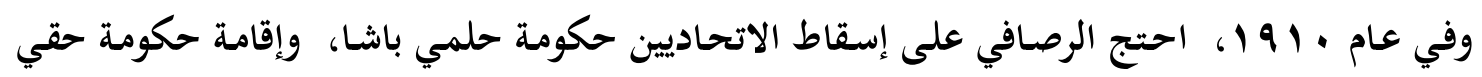
باشا مكانها، منبها إلى أن هذه السياسة التي تهدف إلى إثاعة روح العنف والفوضى بحجة الإصلاح،

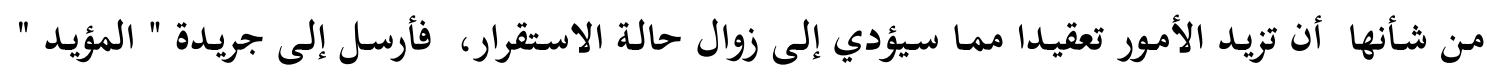
بمصر قصيدة بعنوان " شكوى إلى الدستور" انتقد فيها نهج الاتحاديين الذين كانوا يؤلفون الوزارات من غير رجالهم، ويجعلونها تابعة لهم، وفي هذه المناسبة قال مخاطبا الدستور :

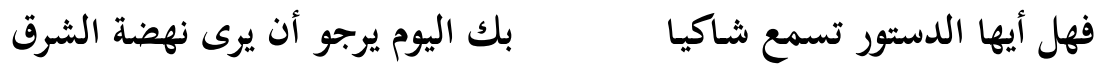

$$
\begin{aligned}
& \text { لقد جئت من أفق الصوارم طالعا علينا طلوع الشمس من منتهى الافق }
\end{aligned}
$$

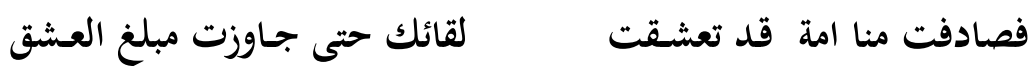

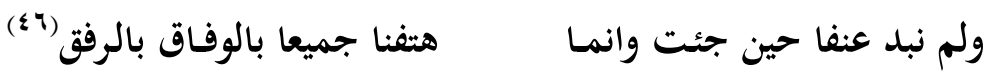

واستمر الرصافي في نهجه المؤسس على التقاطع مع الاتحاديين، حين وجد في سياستهم تجاوزا على

أبناء أمثله، متوعدا هؤلاء بأشد المواجهة والوقوف بوجه تحركاتهم، إذ يقول:

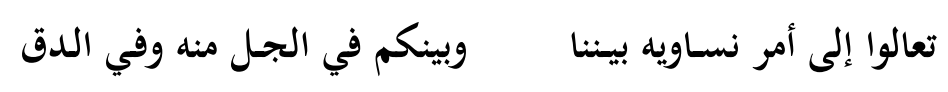$$
\text { فأن يفعلوا هذا فيا مرحبا بهم وإلا فيا سحق المعابد من سحق }
$$

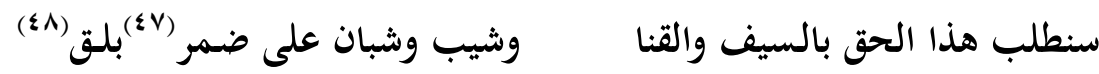

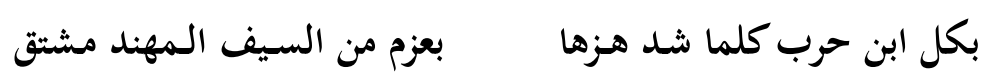


وفي هذه الأثناء، كانت المجالس الأدبية التي اعتاد الشباب البغدادي عقدها، قد شكلت الإطار الذي في داخله، تفاعلت التوجهات السياسية والرؤى والأفكار التي حملها مثقفو تلك المرحلة، اذكان الأخوة حكمـت ومراد وخالد سليمان فائق يجتمعون مع الشـاعر معروف الرصافي في دار الأول مـنهم، ليناقشوا أفكار الأحرار في مقاومة الاستبداد(9 ؛). ومع تزايد الاستبداد العثماني راح الرصافي في أكثر من محفل، يؤكد أن حرية الفكر في بـلاده مهانة، وان الضغط بالفا مبلغه على حرية الصحافة والاجتماع وعلى حرية تأليف الأحزاب السياسية التي لا تقوم الحكومة الدستورية إلا بها(•). وفي مناسبة افتتاح المنتـدى الأدبـي في الأستانة، وقف الرصـافي في مبنى المنتـىى، وألقى قصسيدة في حفـل افتتاحسه، وقصيدتين أخريين في أوقات متفاوتة، كانت أولاها في الحفل الذي أقامه المنتدى في عام 9 ، 9 (، في حين جاءت الثانية في الحفل الذي أقامه في حزيران عام | |9 |، إذ تغنى فيهما بأمجاد العرب وحث أحفادهم على النهوض وتوحيد الكلمة(1)، وقـد اعترف اسعد داغر، بأنه تمكن وحده من توزيع أكثر من مائة نسخة من قصيدة أخرى ألقاها الرصافي في المنتدى(ه). وحين عقد المؤتمر العربي الأول في باريس في حزيران عام با 9 |(זه)، وتم للإصـلاحيين العرب تقديم مطالبهم، فأن الرصافي لم يساوم على المبادئ، بل عمد إلى انتقاد تلك المطالب، معتبرا أنها تقوم على أساس ديني، وراح معاتبا من رحب بهذا المؤتمر، قائلا في قصيدته " ما هكذا " : راموا الصلاح وقد جاءوا بلائحة خرقاء تترك شمل الشعب مشعوبا قد كّلفوا شططا فيها حكومتهم وخالفوا الحزم فيها والتجاريبا عدوا النصارى وعدوا المسلمين بها ونحن نعدهم طرا اعاريبـ(\&) والى ذلك، فقد انتقد الرصـافي راعي هـذا المؤتمر، بل ذهـب إلى وصفهم بـالحملان التي تطلب مساعدة الذئب فهو يقول :

$$
\begin{aligned}
& \text { قل " للعريسي"(ه) والأنباء شائعة والصحف تروي لنا عنه الأعاجيبا } \\
& \text { علام تعقـــ في بـاريس مؤتمرا ماكنت فيه برأي القوم مندوبا }
\end{aligned}
$$

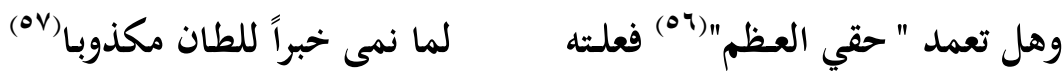

الرصافي و بدايات الحكم الوطني في العراق عام | 9 ا يعد الرصافي أول من دعا إلى قيام النظام الجمهوري، بديلا عن الحكم الملكي، حين أشـار إلى تلك الدعوة في قصيدته " رقية الصريع " التي جاء فيها : 


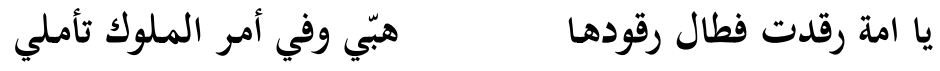

$$
\begin{aligned}
& \text { أيكون ظل الله تارك حكمه المنصوص في آي الكتاب المنزل }
\end{aligned}
$$

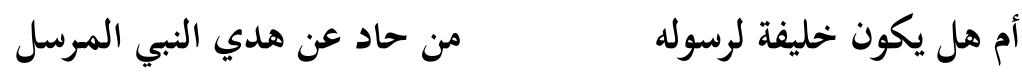

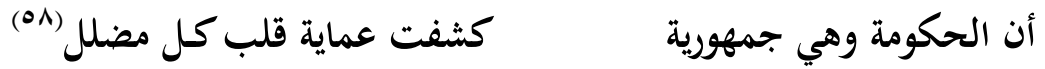

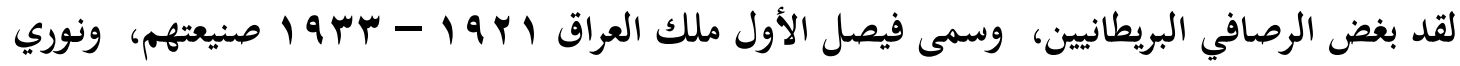
السعيد خدينهم، واعتاد أن يذكر عبارة " الا لعنة الله على الخائنين" مع كل ذكر لنوري السعيد. واللافت للنظر أن الرصافي لم يتوان أن يهجو دولة بملكها وحكومتها ومجلس نوابها وكل دوائرها في قصيدة تجاوز فيها كل ما عرف عن حدود الجرأة وجاءت بعنوان " حكومة الانتداب "(ه). والأكثر من ذلك، انه دعا الناس فيها إلى اعتناق الشيوعية ليتخلصوا من مطامع البريطانيين ولم يقصد من ذلك أكثر من تعبير عن موقف معادٍٍ لهم، بمعنى أن دعوته الناس الى اعتناق البلشفية سيكون فيه ردع للبريطانيين من باب النكاية بهم ليس غير ، إذ قال :

$$
\begin{aligned}
& \text { أنا بالحكومة والسياسة اعرف ألام في تفنيدها وأعنف }
\end{aligned}
$$

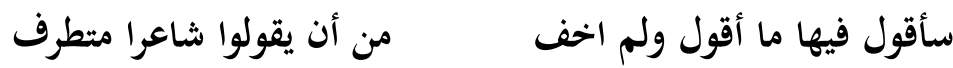

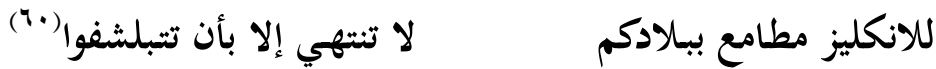

ويمضي الرصافي إلى رسم شكل الدولة القائمة آنذاك بأبيات قليلة، من خلالها تتساقط كل معاني تلك الدولة التنتهي إلى عدمٌ بقوله :

$$
\text { علم ودستور ومجلس امة عل عن المعنى الصحيح محرف (1) }
$$

وفي سياق انتقاده، وعدم قبوله بما يقوم به الساسة والحكومة من إدارة للبلاد، فقد صب جام غضبه

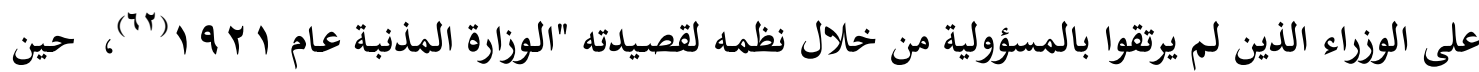
رأى وزراء من دون وزارات، بيد انه لم يوضح أو يشر إلى تلك الوزارات، ووجدناه ينتقد ما يعرف بوزير دولة، مؤكـدا انه أمـر غير مفهوم أو مـألوف. ويبدو انه أراد مـ خلالها طرح أفكار تكـون بـديلا عمـا أساءت استخدامه تلك الوزارة من سلطات ومسؤوليات انيطت بها، فقد انتقد الرصافي المسؤولين فيها

$$
\text { وبأسلوب هزلي ساخر بقوله : }
$$

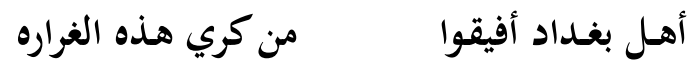

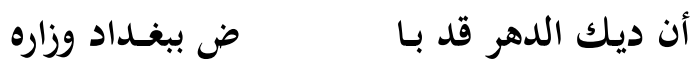

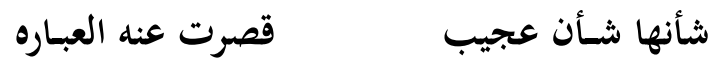




$$
\begin{aligned}
& \text { هل للجـاهل عز ولذي العلم حقاره }
\end{aligned}
$$

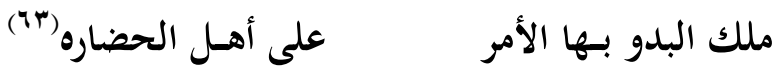

ومما يذكر أن أعضاء الحزبين الوطني الذي كان يرأسه جعفر أبو ألتمن، وحزب النهضة العراقية برئاسة

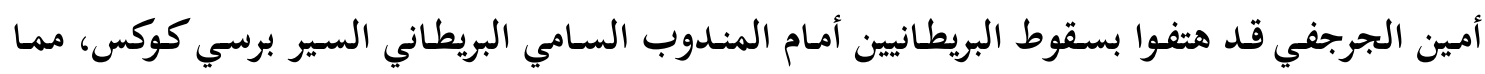
تسبب في غضسبه، فـذهب إلى الملك فيصـل الأول شـاكيا، وكـان الملك يومئل بيـ أيـدي الأطباء لاستئصال الزائدة الدودية، حيث طلب إليه أن يوافق على نفي زعماء هذين الحزبين خارج البلاد، فلما امتنع عن ذلك، تولى كوكس الأمر بنفسه وقام بنفيهم، فكان هذا القرار مدعاة فرح للحزب الحكومي و

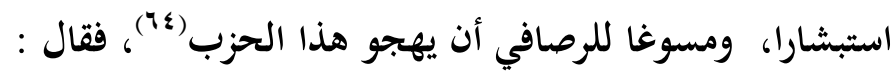

$$
\begin{aligned}
& \text { قولوا لحزب تسمى الحر معتدلا هل أنت من بعد نفي القوم معتدل }
\end{aligned}
$$

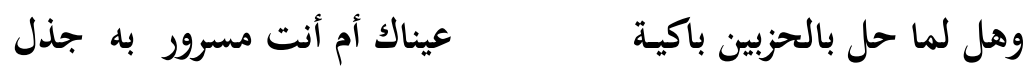

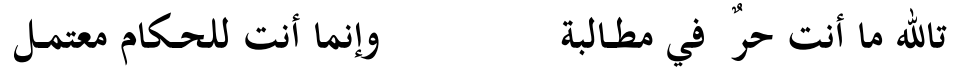

$$
\begin{aligned}
& \text { وما سعيت الى حقٍ لتدركه بل أنت للأمر في مسعاك ممتثل (10) }
\end{aligned}
$$

وحين بلغ هذا الهجاء مسمع عبد الرحمن النقيب، رئيس الحزب الحر قال : " نحن لا نبالي بمثل هذه الأقوال الفارغة "(4") فأجابه الرصافي قائلا :

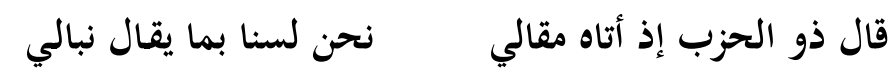

صادق في الذي ادعاه وأنّى ئألم الميت من جروح النصال

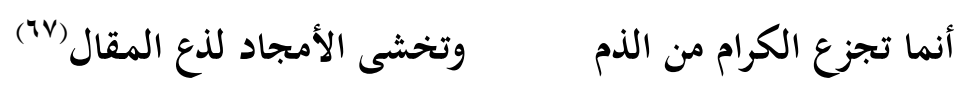

وأمام ذلك كله، يبدو من الصعب وضع اليد على حقيقة هذه المواقف التي أبداها الرصافي، هل هي لهي شحنة من الوطنية ؟ وهو الذي يرى أن العراق ليس سوى وليد غير شرعي أنجبه البريطانيون بل أنجزته

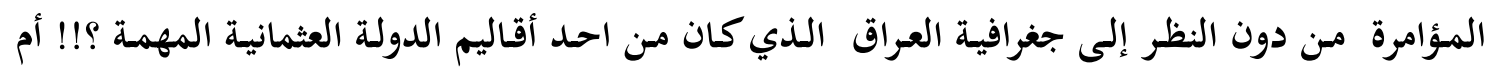
كانت هواجسه الغاضبة بمثابة تعبير عن الحنين إلى العهد العثماني، حيث استقراره النفسي والاجتماعي

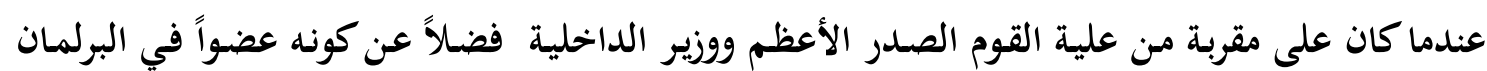

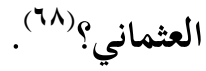
والذي يجب الإشارة إليه، أن التاريخ حافل بفصول من الشجاعة الوطنية للرصافي، كان من أشهرها مراسلاته مع جرترود بيل السكرتير الشرقي للمندوب السامي في العراق، التي ثارت ثائرتها حين علمت لهت بنشاطاته التحريضية، وقصائده السرية المطالبة بإطلاق سراح الزعيم الوطني العراقي جعفر أبو ألتمن 
وسبعة من الوطنيين معه والذين نفتهم السلطات البريطانية إلى جزيرة هنجام عام Y Y I I ـ وقد رد الرصافي على غضـب المسس بيل برسـالة جريئة قال فيها : " أن السياسـة البريطانيـة الخاطئة ستعود بالضـرر على الطرفين العراقي والبريطاني انك ـ يعني المس بيل ـ شخص محترم أولا، لأنك امرأة وثانيا لأنك متعلمة ومتمدنة، ولكـن إذا كنـت تعتقدين بأنك أحق منـي بالأفكار في مصـلحة هـذا الوطن، فذلك شيء لا يسلمه لك الناس ولا يصدقونه، واعلمي أيتها السيدة الفاضلة، أنني قادر على أن أُخلّد لك ذكرا في التاريخ، فاجتهدي أن لا يكون هـذا الذكر إلا حسـنا هـذا، واني لأرجو أن يكون لغضبك عليّ نتيجـة ظاهرة وإلا فالغضب بـلا نتيجة ظاهرة لا يخيف"(9")، وإزاء ذلك لم يكن أمام المس بيل إلا أن ردت عليه بغضب محذرة إياه من مغبة التمادي في التعبير عن الرأي بهذا الأسلوب، قائلة : " هناك حدود للطريقة التي يُعبَر بها عن الآراء ويجب أن لا تتعداها "(•)، فما كان من الرصافي، إلا الرد ساخراً بقوله : " إنني كغيري من الثعراء لا اعلم لطرق التعبير عن المعاني حدودا، غير الحدود التي ذكرهـا علماء البلاغة و الفصاحة "(1)) وهكذا عمدت المس بيل، إلى محاربة الرصافي، بلدل نفيه فلجأت إلى إتباع أساليب خفية منها الضغط على الصحف بعدم نشر قصائده(VI). وعلى الرغم ذلك، فقد استمر الرصافي في انتقاده اللاذع للساسة البريطانيين، كما في انتقاده ل " ولسن" (YT) في قصيدته اللاذعة " ولسون بين القول والفعل " حين وصفه بالمخادع بقوله :

$$
\text { مل مل " ولسون " في السياسة حبلا }
$$

ولعل أحدنا لم يستمتع، بل حفظ الأبيات التي خص بها الرصافي حكومة الانتداب حين قال :

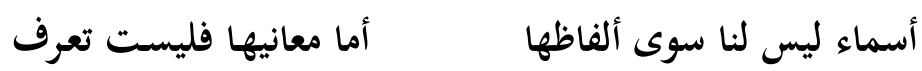

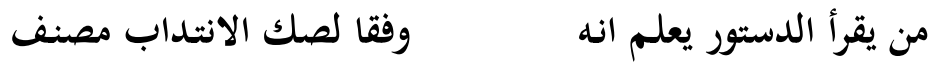

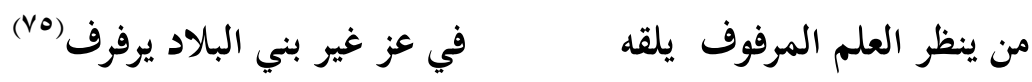

والى ذلك فأن الوزراء في عهد الانتداب البريطاني للعراق، لم يسلموا من نبز الرصافي وانتقاده لهم على أنهم ليسوا في نضره، سوى أدوات بيد البريطانيين، وانهم مجردون من السلطة الحقيقية التي يقبض عليها المحتلون بقوة حين وضعوا مع كل موظف كبير مستشارا بريطانيا، فهزأ بكراسي الوزارة فاضحاً حقيقتها بقوله : (

$$
\begin{aligned}
& \text { هذي كراسي الوزارة تحتكم كادت لفرط حيائها تتقصف } \\
& \text { انتم عليه والأجانب فوقكم كل بسلطته عليكم مشـف }
\end{aligned}
$$


أيعد فخرا للوزير جلوسه فرحا على الكرسي وهو مكتف (Vi")

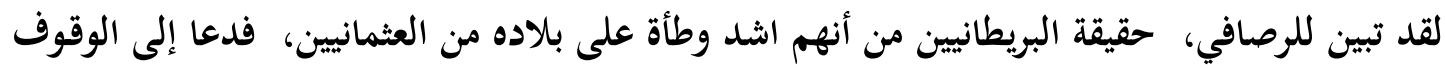

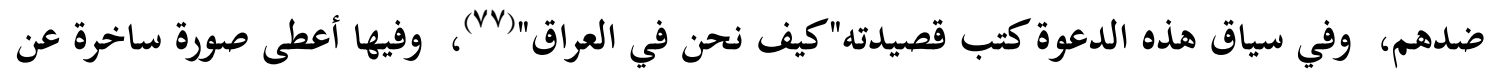

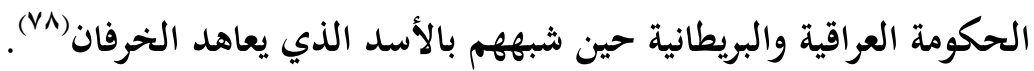

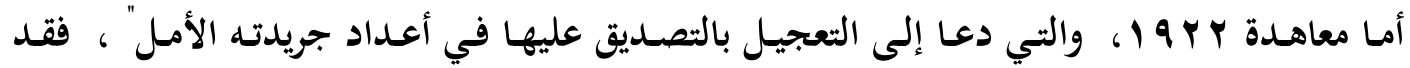
شبهها فيما بعد بالقيد الذي وضع في يد الأسرى، أي الشعب إذ قال عنها : أيكفينا من الدولات أنا تعلق في الديار لنا البنود وأنا بعد ذلك في افتقار إلى ما الأجنبي به يجود (V9)

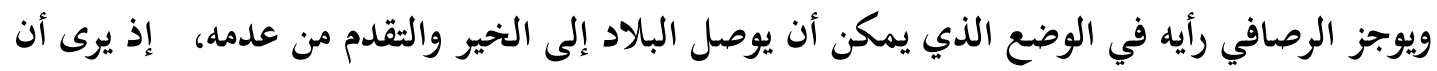

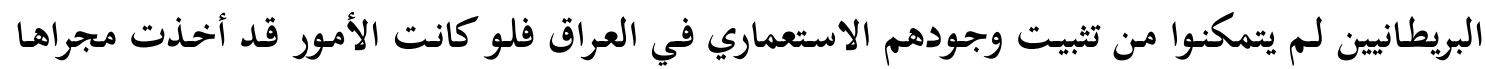

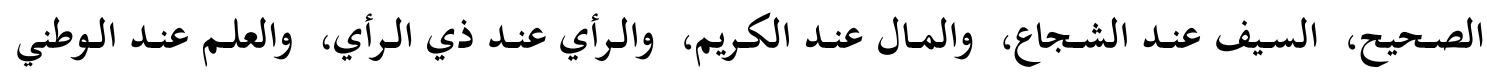
العالم، والحكم عند ابن الشعب الوطني الغيور، لسارت الأمور إلى أحسن منها، ويؤكد أن الأمور قد وضعت في غير نصابها فكانت من العوامل الأساسية التي أعانت البريطانيين على احتلالهم للبلاد (م). الرصافي والصحافة

لقد أستهوته الصحافة وهو في بداية حياته، ويبدو أن الرصافي بما جبل عليه من حب للحرية وتمرد على

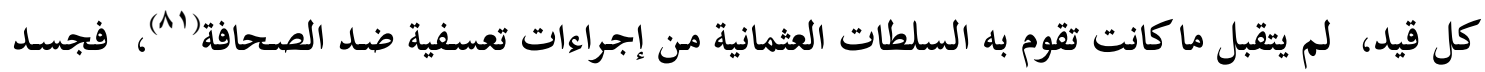
هذا الشعور مستنكرا بقوله :

$$
\begin{aligned}
& \text { أيا حرية الصحف ارحمينا فأنا لم نزل لك عاشقينا } \\
& \text { متى تصلين كيما تطلقينا عدينا في وصالك وأمطلينا } \\
& \text { فأنا منك نقع بالوعود }
\end{aligned}
$$

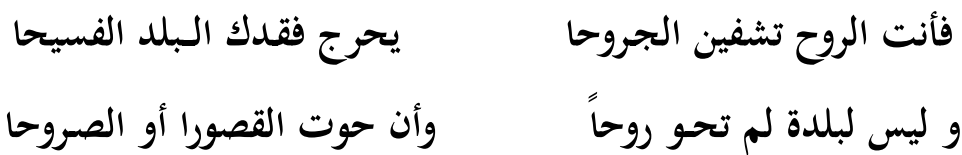

$$
\begin{aligned}
& \text { حياة تستفاد لمستفيدٍ (Nץ) }
\end{aligned}
$$

وعلى وفق ما كان عليه الرصافي من مكانة معروفة في الاوساط الثقافية وكذا الحال لدى الساسة، فقدل

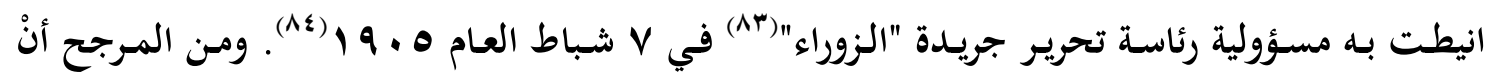
تكون تلك المسؤولية شكلية لم تتعد استعارة لاسمه، إذ لم تشر أعداد تلك الجريدة لأي إسهام أدبي 
فيها، ولمـاكـان أغلب القـائمين بها سواء المحررين او المترجمين لمقالاتها من الأتراك ممـن لم يحسنوا اللغة العربية، فقد أثر ذلك سلبا على مستوى وأسلوب اللغة والمقالات والمترجمات (هo)، الأمر الذي دفع بالرصافي إلى ترك العمل في تلك الجريدة والسفر إلى اسطنبول في عام 9 ـ9 19،

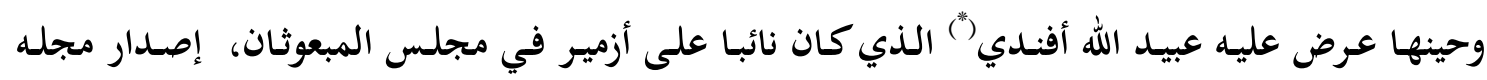

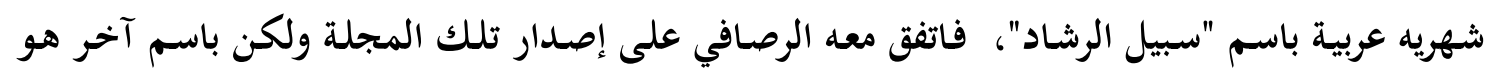
"العرب"، لكن هذه المجلة توقفت بعد فتره قصيرة من صدورها، لأسباب غير معروفة(خآ). وبعد عودة الرصافي إلى بغداد، عمل محررا في مجلة لغة العرب، التي صدرت في أول تموز العام

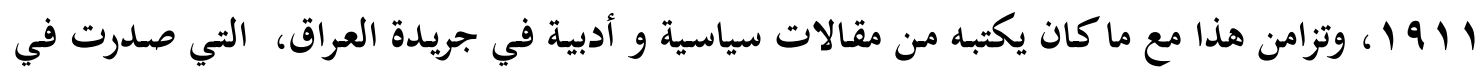

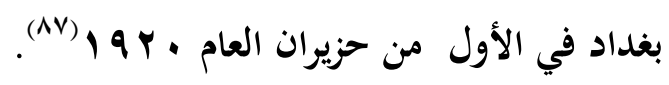
وفي سنة إY ا اقدم الرصافي من القدس الى العراق في عهد حكومة عبد الرحمن النقيب لينضم الى لى الكتلة التي عارضت ترشيح الامير فيصل، وكُلف حينها باصدار جريدة تحمل شعار " العراق للعراقيين ". وتمت الموافقة على العمل لاصدار الجريدة، الا ان ظروفاً - مر ذكرها- وقعت حالت دون الاستمرار

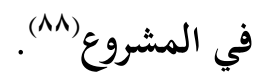
ومن الواضح ان ممارسة الرصافي للصحافة، الى جانب ما كان يختلج في فكره وذاكرته من توجهات ورؤى، كل ذلك هيأ له إمكانية إصدار جريدة تنطق بلسان حاله أسمها " الأمل"، ومع أنها كانت في وقت معين منبرا لترويج الرؤى البريطانية ونهجها، إلا أنها تعد انجازا للرصافي في مجال الصحافة. فقد بـد صدرت بعددها الأول يوم الاثنين الأول من تشرين الأول العام بـ9 19، و تزامن صدورها مع ترشيح الرصافي نفسه للنيابة في المجلس التأسيسي. فجاء في ديباجة الجريدة :سياسية أدبية اجتماعية تصدر

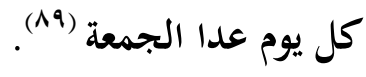
ولعل ما يثير التساؤلات هو تذبذب موقف تلك الجريدة من الوجود البريطاني في العراق، ففي الوقت الذي أعتاد فيسه الرصافي على مهاجمسه البريطانيين وسياستهم الاستعمارية في أغلب مقالاته وقصائده الشعرية - كما مر ذكره - أصبحت جريدة الأمل لسان حال السياسة البريطانية، إذ دافعت عن سياسة الاحتلال وأثنت على المحتلين باعتبار أن الدولة المحتلة وهي" بريطانيا "، صديقة للعراق والداعمة الأولى لبناء دولة عراقية جديدة. وقد غطت الجريدة مراسيم حفلة إزاحة الستار عن تمثال الجنرال مود، الذي أسمته "بمنقذ العراق"، وشادت ببطون الأمهات البريطانيات اللاتي أتحفن العالم بعظماء الرجال فكتبت تقول : " أزيح أول أمس في حفلة شهدها الكبراء والعظماء من البريطانيين والعراقيين، الستار 
عن تمثال الجنرال مود منقذ بغداد سنة 9 ا 19 ـ ونحن هنا لا نريد أن نصف تلك الحفلة ونبحث عن نفسية الذي شهدها وما كان لها من التأثير على قلوبهم وعلى عواطفهم، بل نريد أن نعالج مسألة تاريخية خطيرة تهم العراقيين والبريطانيين على السواء، وهو تأثير إنقاذ مدينة بغداد على يد الجنرال مود، وما لهذا القائد الكبير من المقام الخالد في التاريخ العربي. ويشير المقال إلى أن للجنرال مود مزيتين ترفعانه إلى مصاف أكابر رجـال التاريخ، وقل من اتصف بهما مـن عظماء التاريخ وأبطاله. ويظهر أن البطون البريطانيـة - أكثر مـن غيرهـا - تتحف العـالم مـن حين لآخـر بمثل هـولاء الأفذاذ، الذذين تزدان بهـم صحائف المجد البريطاني" (9.). ومع ذلك فأن جريدة " الأمل " وفي الوقت الذي شادت بالبريطانيين وبحكمهم في العراق فأنها مدت بصرها إلى الأقطار العربية الأخرى منتقدة ومنددة بأساليب فرنسا واسبانيا الاستعمارية في أقطار المغرب

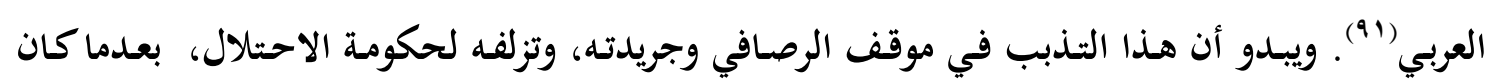
معارضا قويا لها، ناجم عن مزاجه الحاد ونفسه المضطربة المتوثبة، وطابع الحزن والتشاؤم الذي طبع حياته بطابعه الخاص وكذلك مواقفه المتسرعة في بعض الأحيان، فضلا عما أصابه من حرمان، بخروجه من معارضته للبريطانيين من دون حصوله على أي موقع وظيفي في الدولة العراقية الجديدة، الى جانب ما كان يمر به من ضائقته المالية ، كل ذلك أسهم بشكل مباشر في تذبذب مواقفه تلك. وقد تنصل الرصافي فيما بعد عما كان يصدر في جريدته الأمل، حين أنكر ملكية الجريدة وعدم عائديتها له، عندما أكد الى صديقه المحامي محمود العبطه، بأن المرحوم الأستاذ حلمي العمر، ق قد لـ سحبت إجازة جريدته، مما تسبب في فاقته، وهو ما دعا الرصافي حسبما أشار إلى سعيه للحصول لله على امتياز باسم الأمل وكان يتعيش منها، ولم يكن للرصافي من هذه الجريدة إلا الاسم فقط (rه). ومع ذلك فهذه المبررات لم تكن منطقية بمكان، لتسـد تلك الثلمة في سيرة الرصافي حين ناصر ولو لأيام معدودات النهج البريطاني في العراق، فالتاريخ سجل لا يمحى. وفي جريدته الأمل، د دخل الرصافي في العديد من الخصومات مع بعض الشخصيات السياسية العراقية أمثال " محمود النقيب " ابن عبد الرحمن النقيب، أول رئيس وزراء عراقي في العهد الوطني ومؤسس الحزب الحر المعتدل "، كما مر ذكره، والصحافي إبراهيم صالح شكر، والشاعر جميل صدقي الزهاوي • فقد كانت مقالات الرصافي ومساجلاته في رده على خصومه ومنتقديه لا تخلو في بعض الأحيان من التشهير أو الخروج عن اللياقة الأدبية، ويبدو أن جريدة العراق، لصاحبها رزوق داود غنام' ذاقت ذرعا بما يطرحه الرصافي، فدخلت معه في مشادة وجدل عنيفين بالرغم من كونهما " أي الأمل والعراق " 
جريدتين مؤيدتين للسياسية البريطانية ويجمعهما اتجاه واحد، إلا أن جريدة العراق كتبت تقول ساخرة من طروحات الرصافي : " مسكين هذا الشاعر - وتقصد الرصافي - تلعب به العواطف وتحركه اللبانات، فيندفع إلى حيث يجد فسحة الأمل - أي جريدة الرصافي - ما أضيق العيش لولا فسحة الأمل" (זه). واستمرت جريدة العراق في حملتها على جريدة الأمل وعلى رئيسها الرصافي، بل حاولت في مقال عنيف لها تحريض الحكومة ضده. فكتبت في إحدى افتتاحياتها ما نصه : " أن سكوت الحكومة العراقية عن مساوئ معروف الرصافي وتناسيها جناياته المتتابعة، هو الذي ضم إليه أولئك الأفراد وما غرر البعض بشـهرته، وإنها لـو علمـت - أي الحكومـة - واجبـات القانـون في التنكيـل بـه وبأمثاله، مـن الخونـة المارقين، لجنبت بعض السذج عدوى تضليله وتدجيل أمثاله، ولما ذ ذعن أولئك الفتيان، يتغلب عليهم نزق الشباب وغرور الفتوة، فيغالطون أنفسهم ليغفلوها عن هذه الجرثومة الفاسدة" (\&9) . وفي الوقت الذي كانت فيه جريدة العراق مستمرة في حملتها ضد الرصافي هاجمت جريدة "الناشئة" الجديـدة لصـاحبها إبـراهيم صـالح شـكر، والـذي ارتبط بصـداقة مـع الرصـافي عنـدما كـان الاثنـان في اسطنبول، بعدما ساءت علاقة الرصافي به لأخذه وظيفة كان من المقرر أن يشغلها الرصافي، مما تسبب في قيام العداوة بين الطرفين. ولعل الاختلاف الفكري بين الشخصين، قد أسهم بشكل أو بأخر في تأجيج هذه الكراهية، فكان "شكر" شـيد الاختلاف مع الرصافي كونه كان من دعاة تيار العروبة في

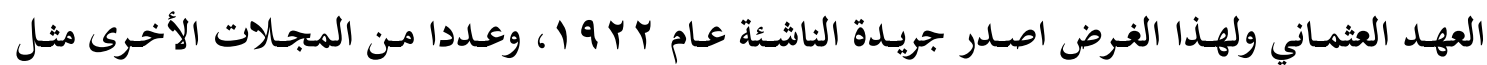
المعارف والرياحين والعهد العثماني، مهمتها الدفاع عن هذا التيار والعمل ضد جمعية الاتحاد والترقي، فعوقب بالنفي من بغداد إلى الأناضول متهما بالخيانة العظمى بعد أن مكث في السـن أربعة أشهر (99). وبعد عودته إلى بغداد، اعتزل "شكر" الحياة وأمضاها في بيته لشدة ما قاساه وما عاناه، في حين كان الرصافي يساير أعضاء جمعية الاتحاد والترقي ونائبا في مجلس المبعوثان، فهجاه شكر أيما هجاء، وفي إحدى مقالاته في جريدته الناشئة كتب شكر، قائلا : " إن الرصافي هو واحد ممن يماشي السلطة في أي مكان وزمان"(هو)، وقال عنه :" انه تركي مع الترك وعربي مع العرب وأجنبي مع الأجانب، وانه مدح الطغاة وأصحاب المال وتسول في شعره عندما اخذ من الشيخ خزعل · . . ع روبية ومبلغا من فخر الدين الجميل وغيرهم" (9v) وفي مقال آخر لا يخلو من التجريح، كتب شكر في جريدته الناشئة مقالا تحت عنوان : " معروف الرصافي يستجدي بشعره " قال فيه : " عزمنا على نشر عدد خاص من الناشئة الجيـدة يوم الثلاثثاء المقبل، وفيه كحل القصـائد التي نشرها الرصـافي في طعن الأمـة العببي وعظمائها، 
والشخصيات الكبيرة في العراق مع التعليق على كل قصيدة، لنظهر لمن يجهل هذا المخلوق حقيقته بكل وضوح" (9A)

وبالمقابل فأن الرصافي، هو الآخر قد هجا شكر وقال فيه ما لا يرضاه هو في نفسه، حين كتب في جريدته الأمل، مقالا عنيفا لا يخلو من التجريح، إذ عده صاحب الناشئة: " بماج الذوق ويتبرأ منه الأدب العصري بعدما كانت تعتقد فيه من نزاهة الوجدان وطهارة الضمير.. " (99)

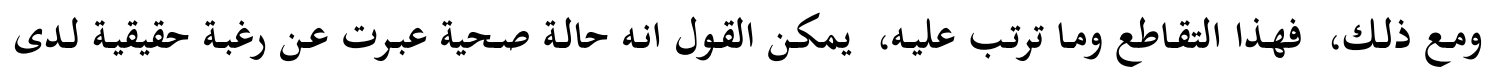
هولاء للعودة إلى الوضع الطبيعي لبلادهم، الوطن العربي الأم، فما الاختلاف والانتقاد إلا ردة فعل لعدم بلوغهم ما يسعون إليه وهم ممن أدرك وميز تعسف الدولة العثمانية وسحقها لحقوق شعبهم . والى ذلك، اهتمـت الأملـ، بقضـايا تحرير المـرأة والمجتمع والانعتاق نحو الحريـة وترك الخرافـات

والبدع، ففي قصيدة للشاعر الرصافي بعنوان : " نساؤنا " نشرتها الجريدة، جاء فيها:

$$
\begin{aligned}
& \text { فتلك التي مازلتُ ابكي لأجلها بكاء إذا ما اشتد أدى إلى الصرع }
\end{aligned}
$$

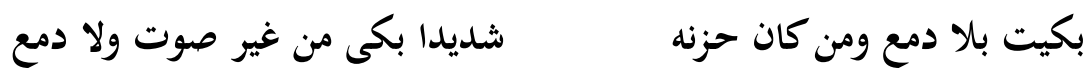

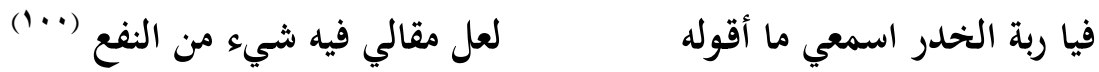

وفي قضية السفور والحجاب، كان الرصافي وجريدته الأمل على رأس المناصرين لحقوق المرأة في هذا المجال، باعتبار أن الحجاب هو من التقاليد التي تحد من حريتها،لكن الرصافي دعا إلى السفور المحتشم، إذ قال في قصيدة له :

$$
\begin{aligned}
& \text { تركوا النساء بحالة يرثى لها } \\
& \text { قل للالى ضربوا الحجاب على النسا افتعلمون بما يجري تحت العبا }
\end{aligned}
$$

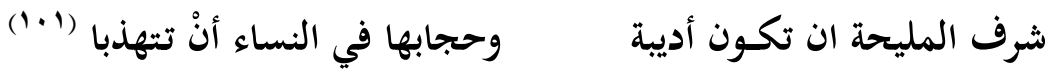

وناصر الرصافي في دعوته هذه، الشاعرين الزهاوي وخير الدين الهنداوي وغيرهم، فيما هاجمه دعاة الحجاب بكل عنف حين قال عنه محمد بهجة الاثري " انه طالب خلاعة وانه جاهل، ثم رماه بالكفر والضلال" في حين أسماه الشاعر إبراهيم الرحيمي، ب" المارق التافه الذي خرق العادات" وقال فيه :

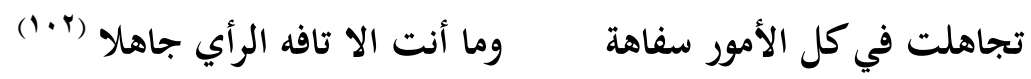

وقد انحازت "الأمل" في أواخر أيامها الى سياسة عبد المحسن السعدون مؤسس حزب التقدم بعد انبثاق

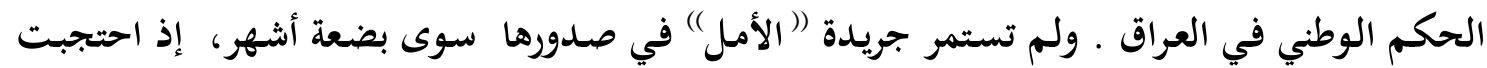

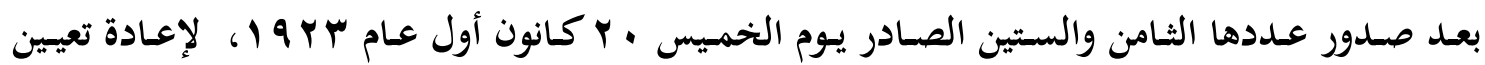


صاحبها مفتشا للغة العربية بوزارة المعارف عام ع ب 1 1، فضلاً عن إلقائه محاضرات في الأدب العببي على المعلمين وتدريسه المادة ذاتها لطلبة الصفوف المنتهية في دار المعلمين العالية في بغداد، التي لهي

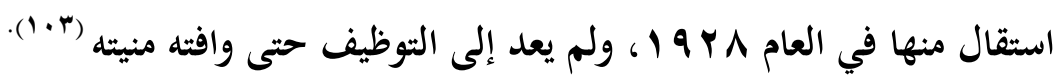
ومن الجدير بالذكر أنَ الرصافي، قد حرر وكتب بعض من مقالاته السياسية والأدبية وبعض أشعاره في لئي

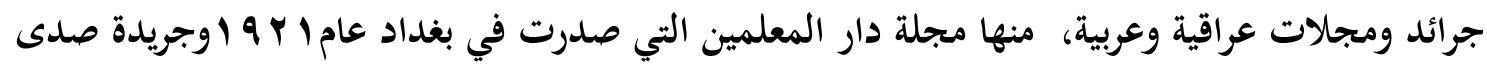

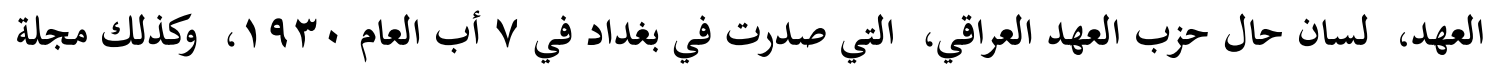

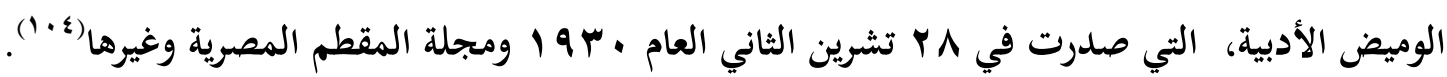

الخاتمـة

في سنوات عمره السبعين شهد الرصافي متغيرات كثيرة، إذ رأى بأم عينه كيف تراكمت الويلات

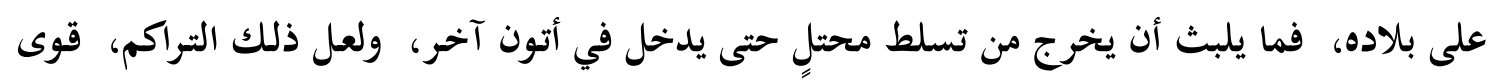

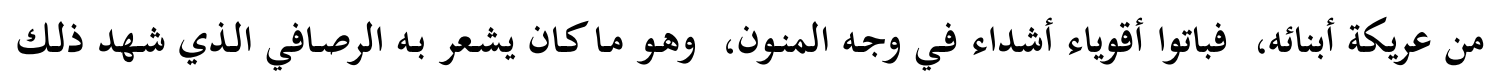
الفصل بكل تُرّهاته وسلوكيات ساسته، وعلى الرغم من كل ذلك، و وجد أن هذا الشعب كان ينقصه قيادة

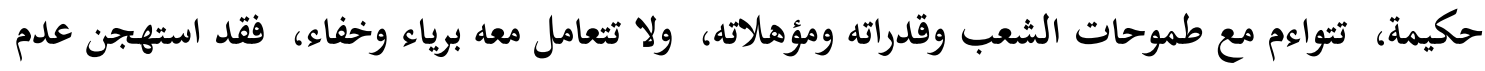
تعامل الحكومة مع الحقائق، وهي العليمة بوضع شعبها ومأساته.

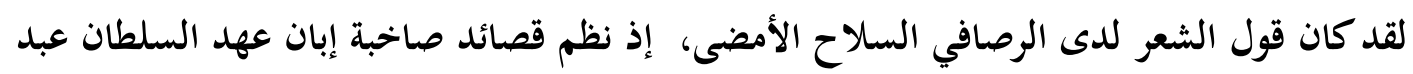

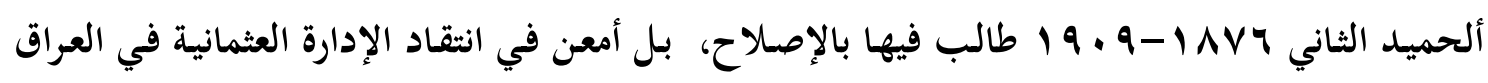

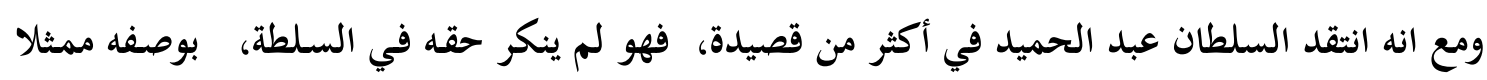

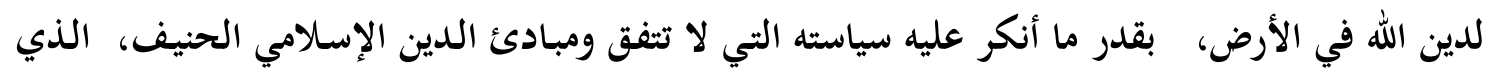

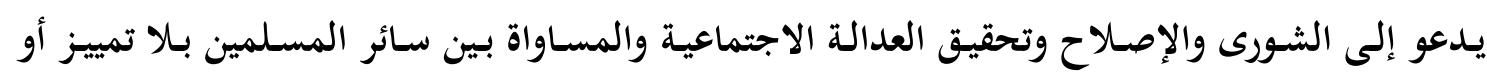

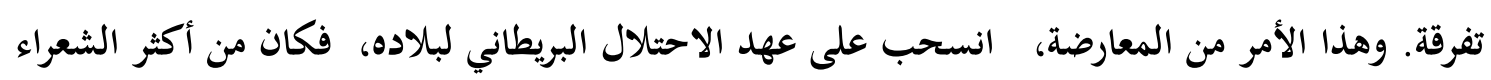

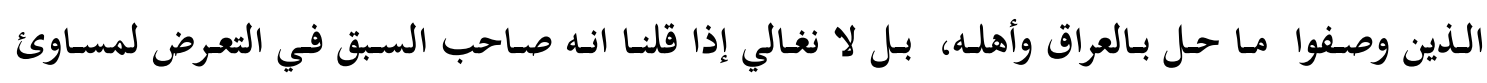

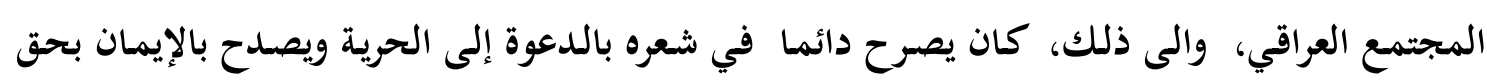

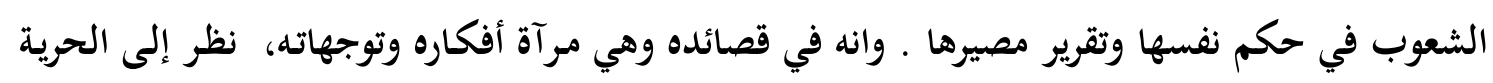

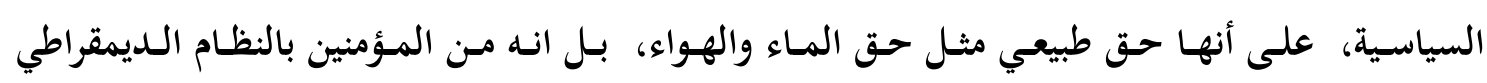

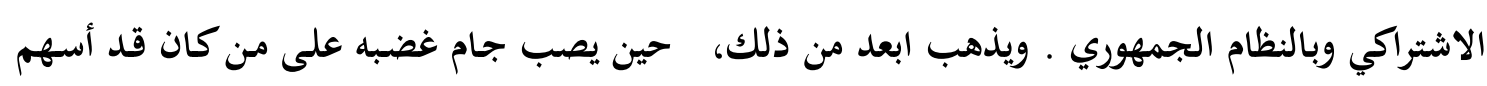


في تحجيم حرية البلاد باستنادهم إلى المحتل، أنى كان مصدره . فقد حمل حملة شعواء باللوم الشديد على المصلحين الذين وضع يـده في أيديهم، ورجـا للبلاد خيرا من حركتهم، إلا أنهم نكثوا العهد

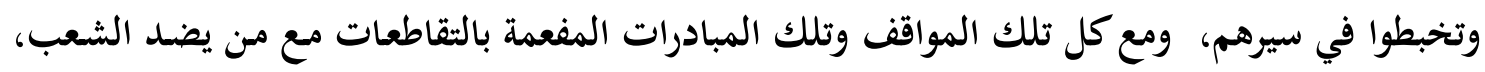

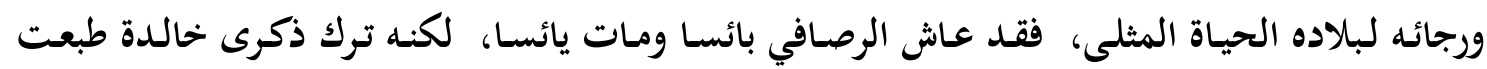
بالنور، فأصبح شهيدا باسم الحرية التي قدم نفسه قرباناً لها، فضرب مثلا سيبقى أبلغ درس لرواد الفكر

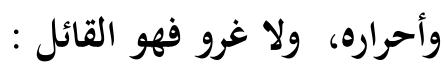

تعودت أن لا أستنيم إلى المني وأن لا أرى إلا بهيئة ثائرٍ وأن أمضي الهم الذي هو مقلقي بطي الفيافي أو بخوض الدياجر (1.0) ثم يقول وهو الصادق الذي بر بكلمته : أبى الحق إلا أن أقوم لأجله على الدهر في كل المواطن ثائرا وأن أتمادى في جدال خصومه و أقرع منهم بالبيان المكابرا (1.4) وقد يطول الحديث بنا، إذا أردنا أن نتحدث عن مناقب الرصافي ومكانته ومآثره الكثيرة، الذي كان صادقاُ مع نفسه ومـع التاريخ، لكننا آثرنا أن نختم ذلك، بما قاله عنده ثلاثة من كبار علماء الأدب والشعر. فقد كتب المستشرق الروسي الأستاذ أغناطيوس تشفويفسكي، ما نصه :" الرصافي يمتاز بعبقرية

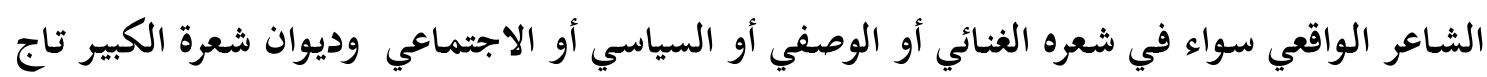
آثاره " (V·1)، فيما كتب الأديب المصري زكي مبارك ، مقالا بعنوان " كيف رأيت الرصافي " جاء فيه : " ل الرصافي هو مجموعة طريفة من العقل والأدب والذوق والذكاء، هو صورة صادقه للروح البغدادي الروح المرح الطروب، هو عنوان الرجولة الصريحة التي تمقت الكذب والرياء، هو بالتأكيد من أثمن ذخائر العراق " (^•1)، وقال عنه الشاعر الصيني الكبير جونس جي عضو مجلس السلام العالمي، ما نصه : ".. ما رأينا الشاعر الرصافي بأعيننا ولكننا قرأنا أشعاره المملؤة بالحرية والحياة.. ليس الرصافي شاعر الشعب لهب العراقي وحده،بل هو شاعر الشعب الصيني.. وقد نقلت بعض قصائد الرصافي الى اللغة الصينية وجمعتها في ديوان الشعراء العراقيين ونالت اعجاب القراء.. وسوف ينقل الى لغتنا ديوانه.. "(1.") . 


\section{Coclusion :}

In his seventy years, Al-Rusafi witnessed many changes. He saw with his own eyes how the calamities accumulated over his country, and he soon emerged from the domination of an occupier until he entered another furnace. Perhaps that accumulation was a force from his children's slave, and they became strong and strong in the face of the Manoun, which is what Al-Rusafi, who witnessed that separation, felt all his nonsense and the behavior of his politicians, and despite all this, he found that this people lacked a wise leadership, compatible with the aspirations of the people, their capabilities and qualifications, and did not deal with it innocent and invisible. He deplored the government's failure to deal with the facts, which are Knowledgeable about the situation of its people and its tragedy.

Saying poetry to al-Rusafi was the most powerful weapon, as he arranged noisy poems during the reign of Sultan Abdul Hamid II 18761909 in which he demanded reform, but rather criticized the Ottoman administration in Iraq and even though he criticized Sultan Abdul Hamid in more than one poem, he did not deny his right to Power, as the representative of God's religion on earth, insofar as he denied to him his policy that is inconsistent with the principles of the true Islamic religion, which calls for consultation, reform, social justice, and equality among all Muslims without distinction or discrimination. And this matter of the opposition, he withdrew during the era of the British occupation of his country, and he was one of the most poets who described what happened to Iraq and its people, but we do not exaggerate if we say that he is the first to be exposed to the disadvantages of Iraqi society, and to that, he was always declaring in his poetry a call to freedom and true to faith The right of peoples to rule themselves and self-determination. And that in his poems, a mirror of his thoughts and directions, he viewed political freedom as a natural right like the right to water and air, and he is even a believer in the socialist democratic system and the republican system. And he goes further, when the anger of his anger is directed at those who had contributed to limiting the country's freedom by relying on the occupier, whatever his source. He carried the campaign of indecent blame on the reformers who put his hand in their hands, and hoped the country better than their movement, but they reneged on the covenant and floundered in their path, and with all these positions and those initiatives filled with 
intersections with those who oppose the people, and his hope for his country the best life, so Al-Rusafi lived miserable. He died in despair, but he left an immortal memory printed in the light, and he became a martyr in the name of freedom, which he offered himself as a sacrifice for him.

I used to not be accustomed to semen and to only see a rebel figure

And to go through the worry that is my concern Bati Al-Fayafi or for running in Al-Daijar

Then he says, and he is the truthful one who justified his word:

I refuse the truth, except that I stand for it forever in every citizen revolting

And he went on with the arguments of his opponents and dubbed them with the tainted statement

The talk may be long for us, if we want to talk about Al-Rusafi's conditions, status, and many exploits, which was true to himself and with history, but we chose to conclude that, with what three leading scholars of literature and poetry said about him. Russian orientalist Professor Ignatius Chvoyevsky wrote what he wrote: "Al-Rusafi is distinguished by the genius of the real poet, whether in his lyric, descriptive, political, or social poetry, and the poetry of the Great Diwan, the crown of its effects" (), while the Egyptian writer Zaki Mubarak wrote an article entitled "How I saw Rusafi" It says: "Al-Rusafi is a quirky group of mind, literature, taste and intelligence. It is a true picture of Al-Baghdadi's soul, the humorous spirit of Tarob, which is the title of frank manliness that abhors lying and hypocrisy. He is definitely one of the most valuable ammunition in Iraq." The World Peace Council states, "What we saw was sha R. Al-Rusafi with our own eyes, but we have read his poems full of freedom and life .. AlRusafi is not the poet of the Iraqi people alone, but he is the poet of the Chinese people .. I have transferred some of Al-Rusafi's poems to the Chinese language and collected them in the Office of Iraqi poets and won the admiration of readers .. He will transfer to our language his office.

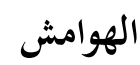

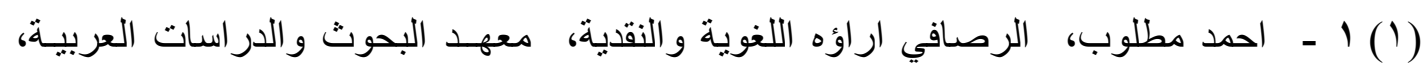

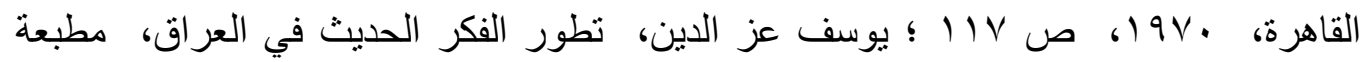

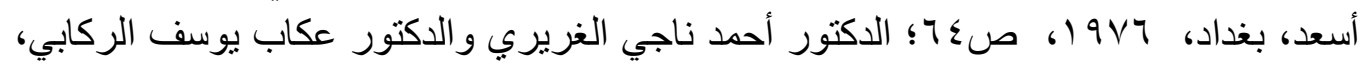




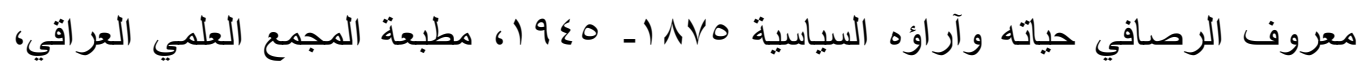

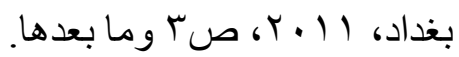

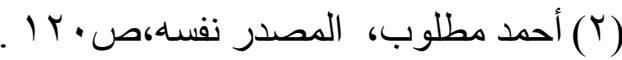

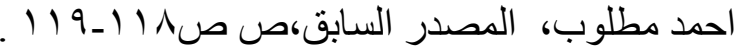

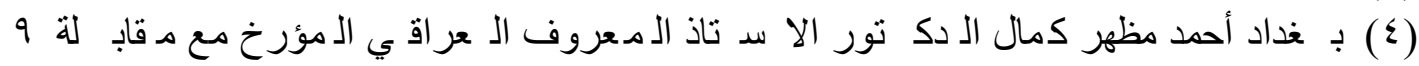

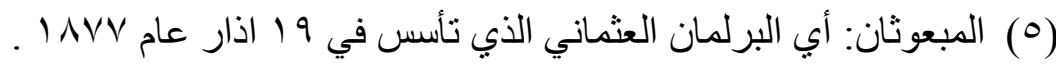

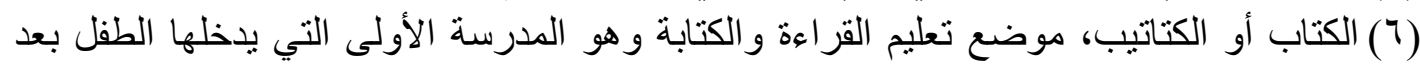

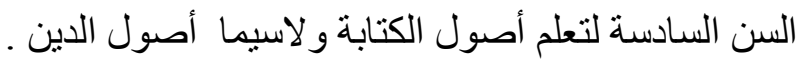

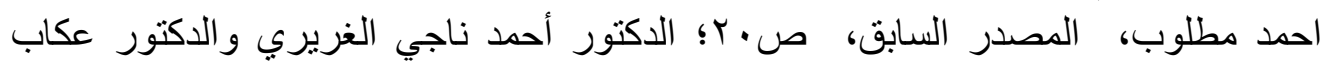

$$
\begin{aligned}
& \text { يوسف الركابي، المصدر السابق، ص. ب وما بعدها. }
\end{aligned}
$$

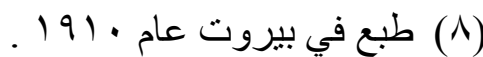

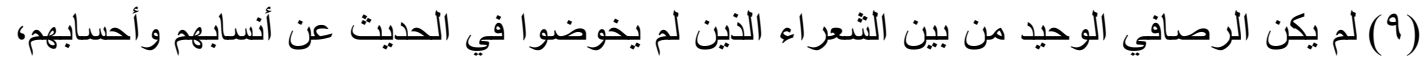

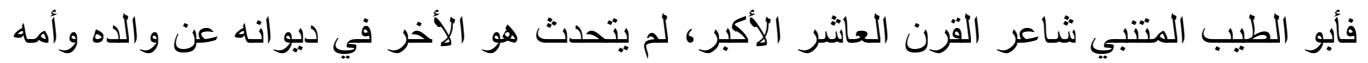

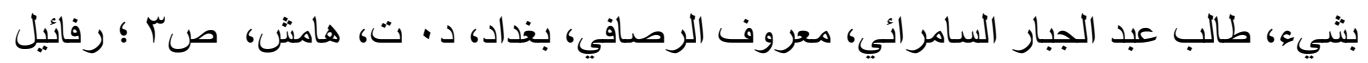

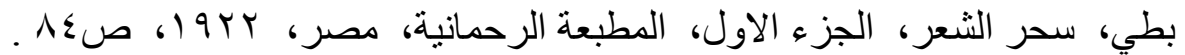

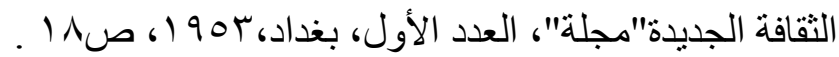

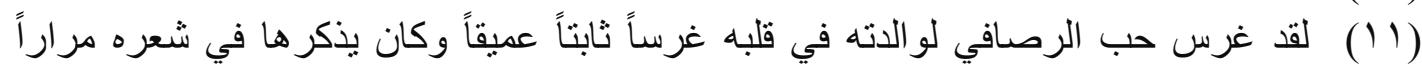

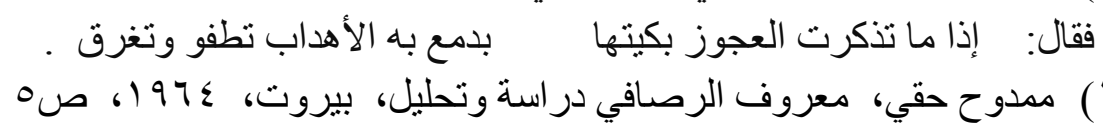

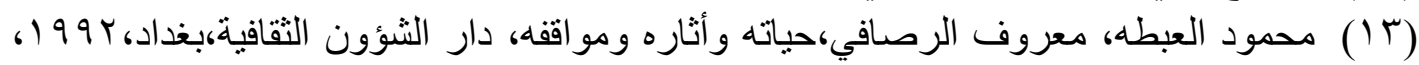

كتاب الأجرومية مختص بالنحو للشيخ محمد بن عثيمين رحمه الله .

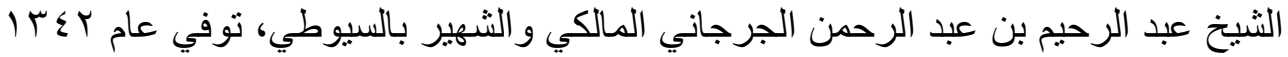

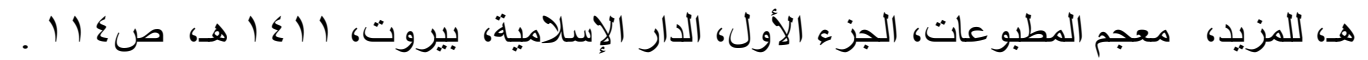

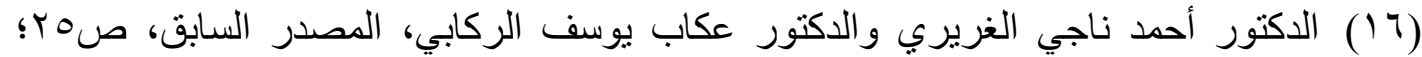

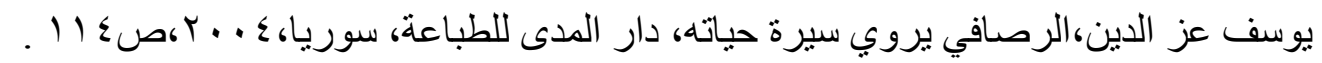

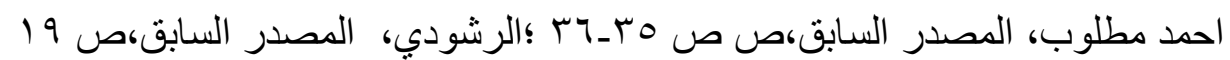

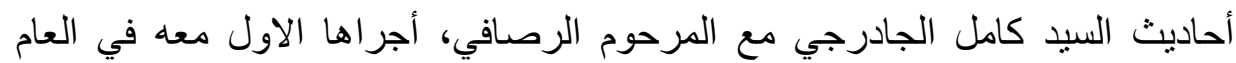

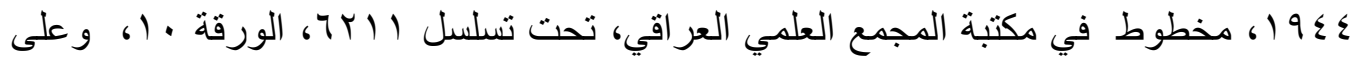
الرغم من نشر تلك المخطوطة، الأ اننا أثرنا الاعتماد على النص العخطوط لكون الناشر اغفل

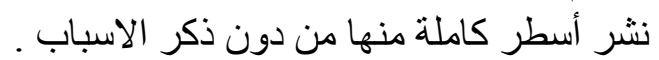

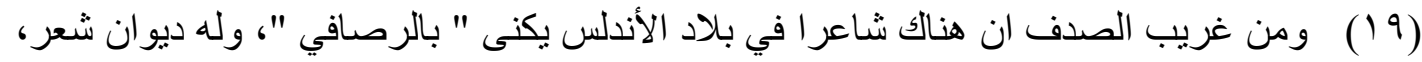

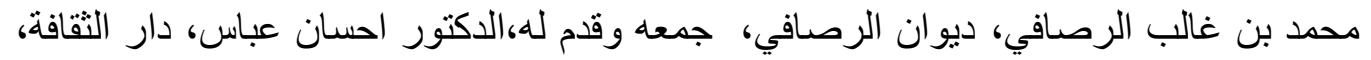

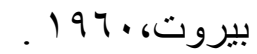

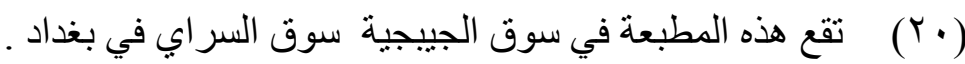

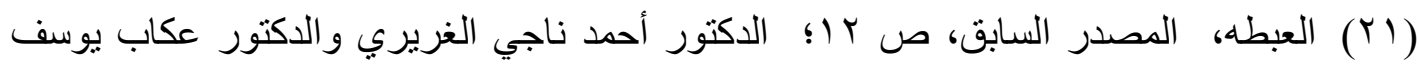

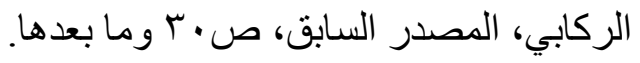




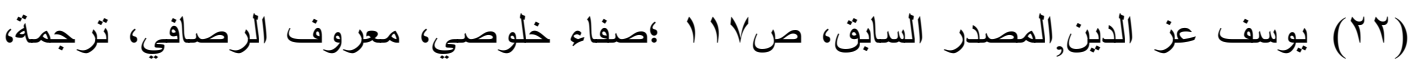

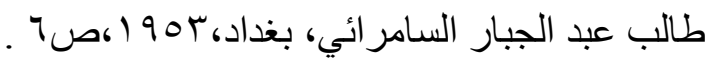

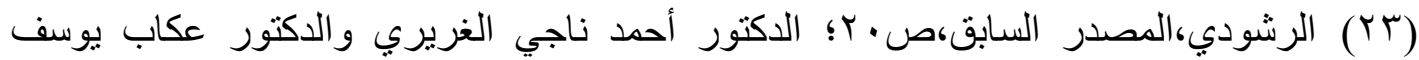

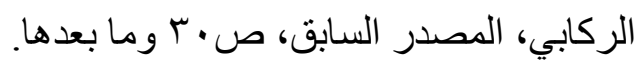

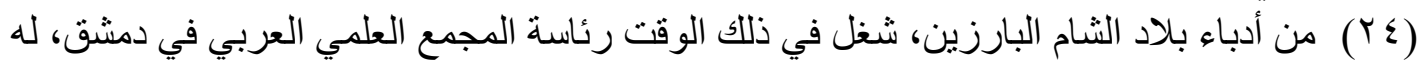

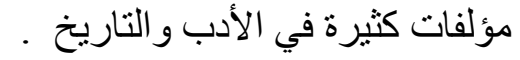

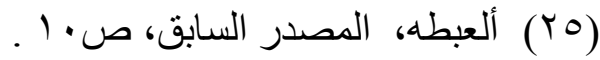

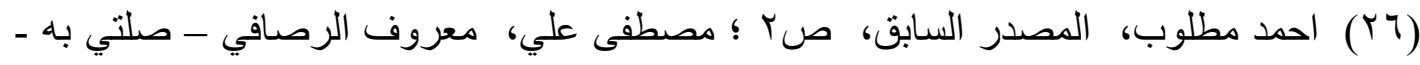

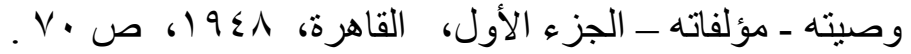
(YV)

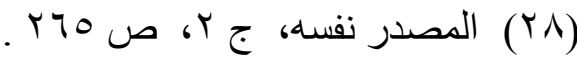

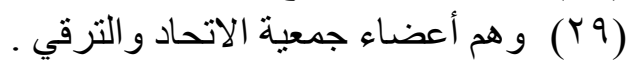

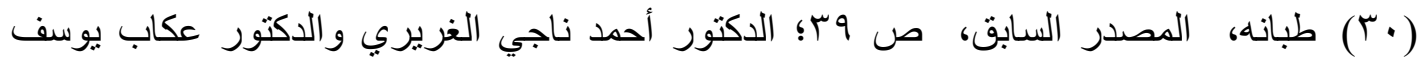
الركابي، المصدر السابق، صنانه المه وما بعدها.

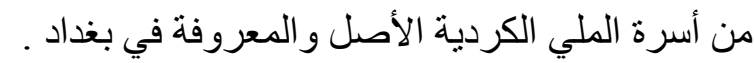

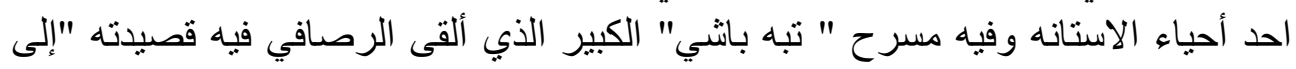

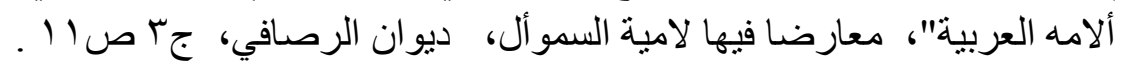

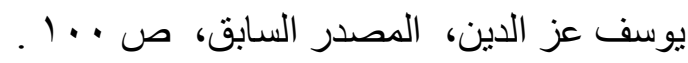

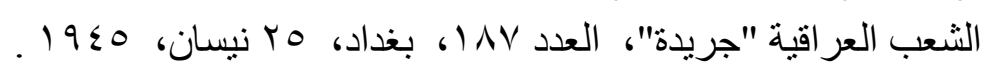

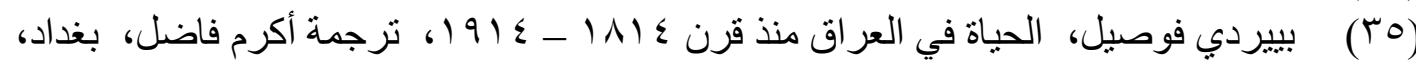

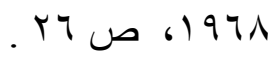

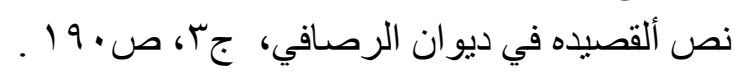

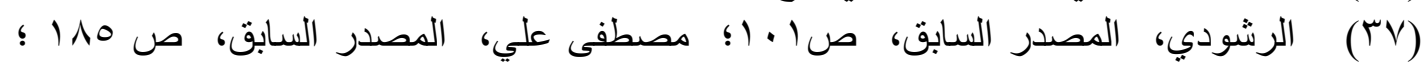

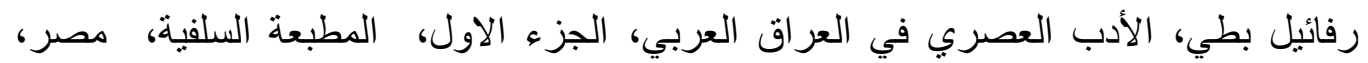

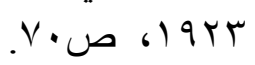

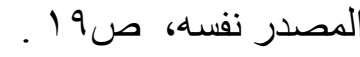

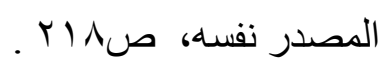

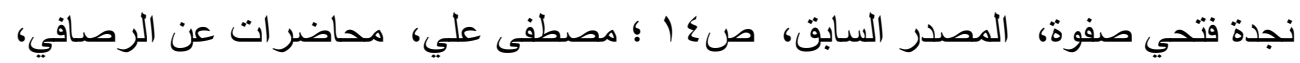

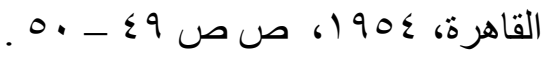

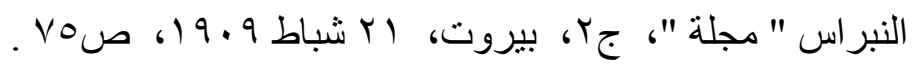

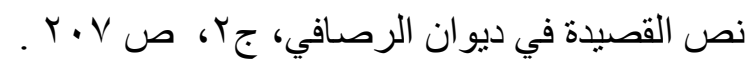

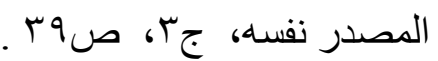

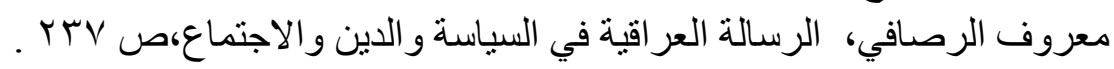

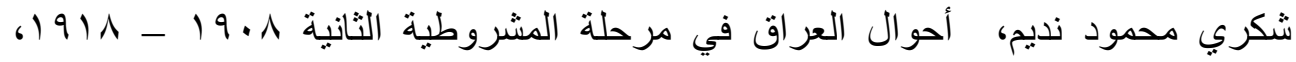

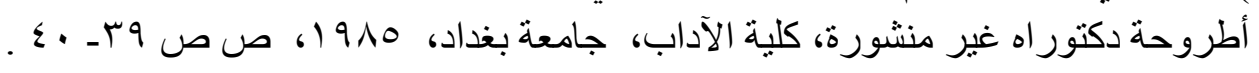

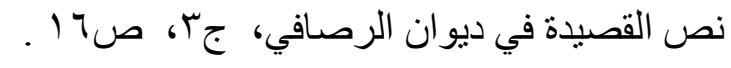

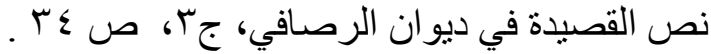

على خيل ضمر بلق، جمع ضامر وهو القليل اللحم والدقيق، وجمع ابلق، وهو، وهو الذي فيه

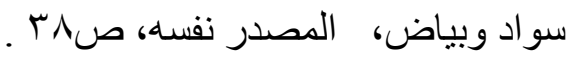


(0) (هبد الرزاق احمد ألنصيري، دور المجددين في الحركة الفكرية والسياسية في العراق

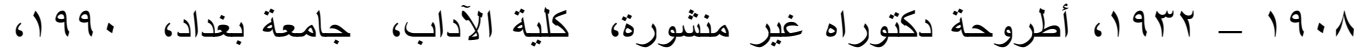

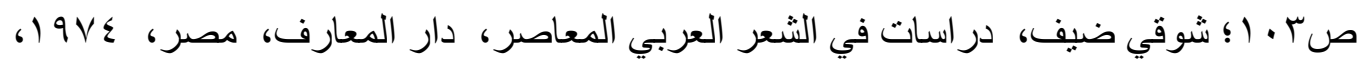

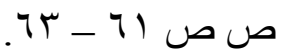

معروف الرصافي، آراء الرصافي في الدين والسياسة والاجتماع، جع و ترتيب سعيد

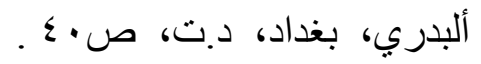

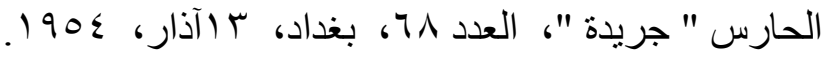

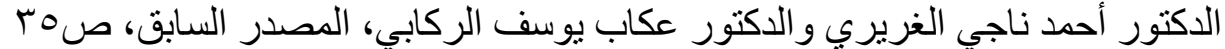

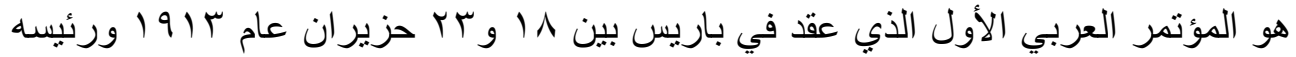
عبد الحميد الزهر اوي، للمزيد محب الدين الخطيب، المؤتمر العربي الأول، المطبعة السلفية،

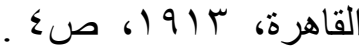

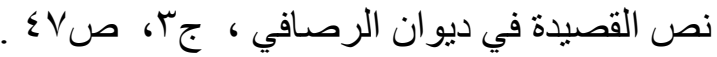

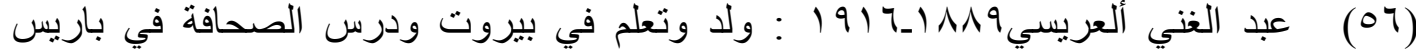

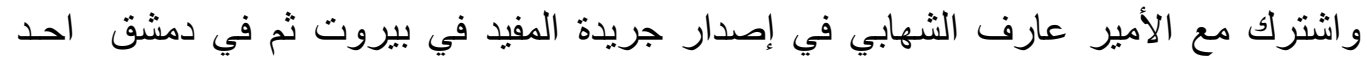
منظمي المؤتمر العربي الأول في باريس وسكرتيره، كان العريسي كاتبا جميل الأسلوب ووطنيا

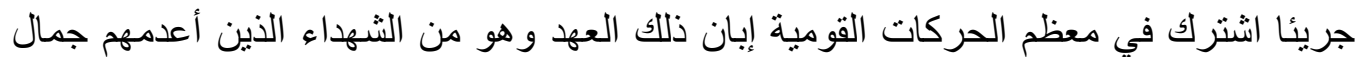

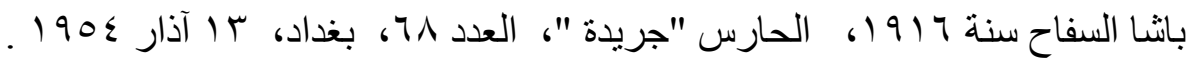

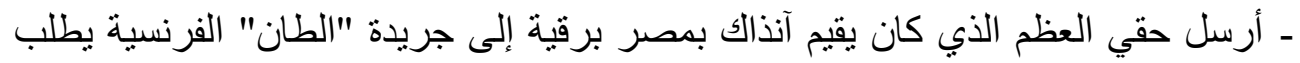

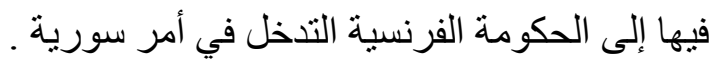

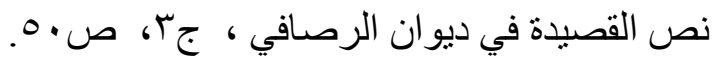

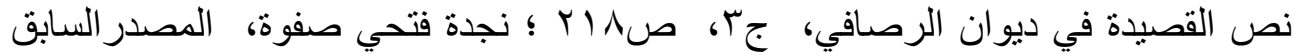

$$
\text { ص ص (17) }
$$

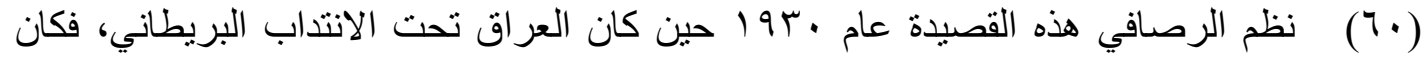

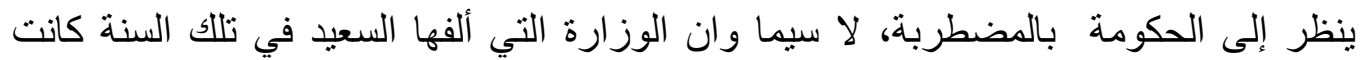

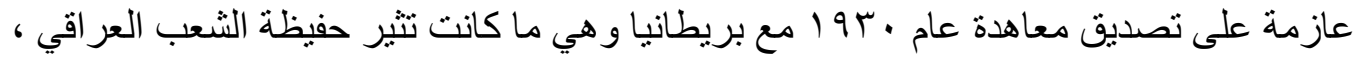

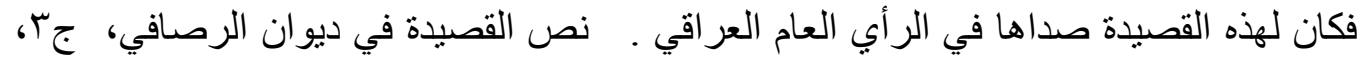

$$
\text { ص صن } 171)
$$

"البلثفيك" او "البولثفييك": اصطلاح روسي معناه "فئة الاكثرية"، يعود تاريخ هذا

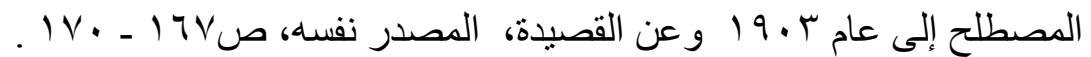

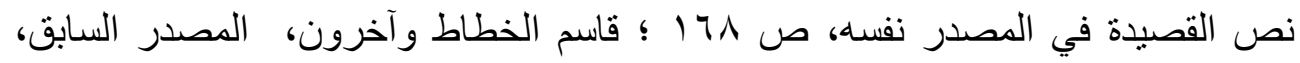

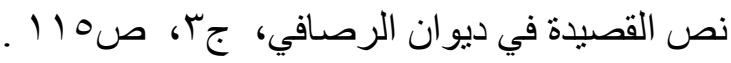

$$
\begin{aligned}
& \text { المصدر نفسه، صئ10 } 110 .
\end{aligned}
$$

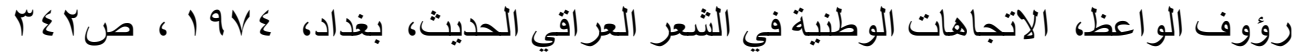

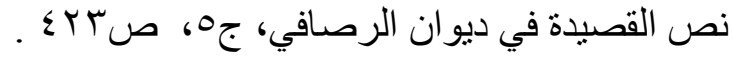

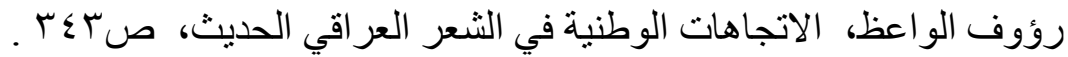

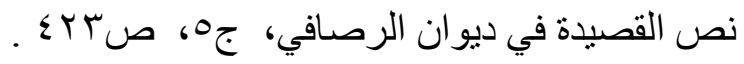




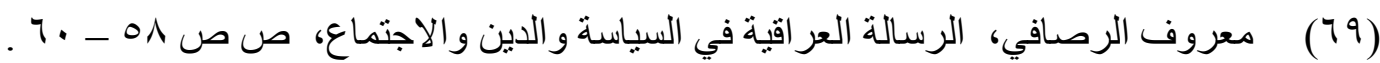

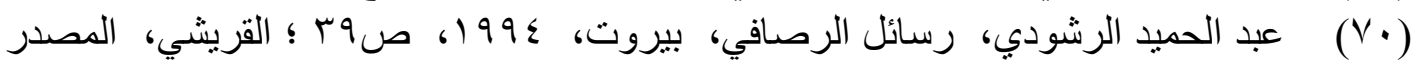

$$
\begin{aligned}
& \text { السابق ص صY IVY. } \\
& \text { المصدر نفسه . } \\
& \text { المصدر نفسها . المديه . }
\end{aligned}
$$

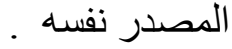

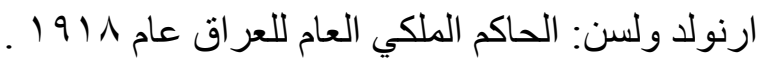

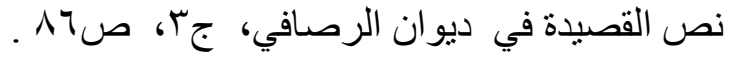

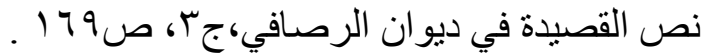

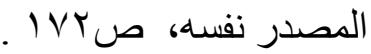

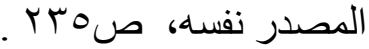

$$
\begin{aligned}
& \text { المصدر نفسه . }
\end{aligned}
$$

معروف الرصافي، ديوان الرصافي، المجلد الثاني، منشورات دار العودة، بيروت، به19 ا،

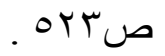

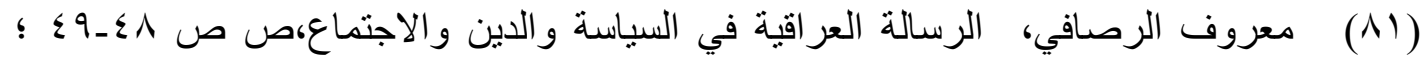

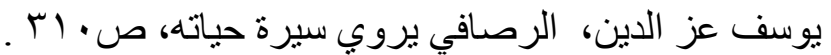

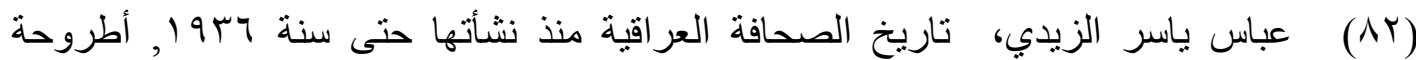

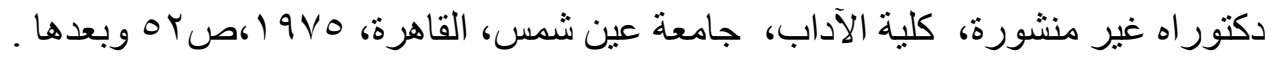

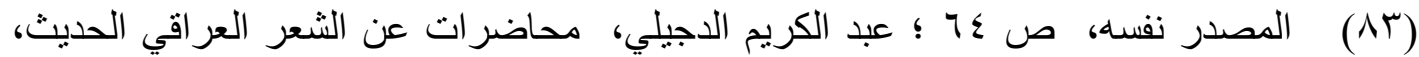

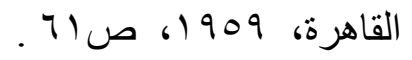

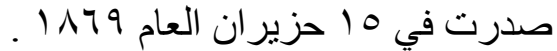

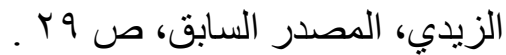

$$
\begin{aligned}
& \text { المصدر نفسه . الزئ. }
\end{aligned}
$$

(N*) - عبيد الله أفندي: نائب عربي في مجلس المبعوثان العثماني، ارتبط مع الرصافي بعلاقة متينة .

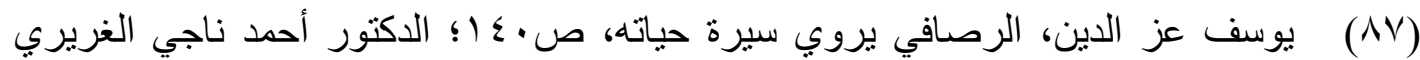

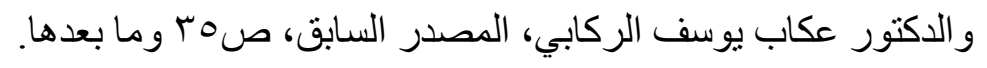

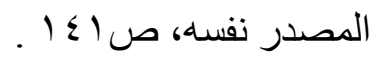

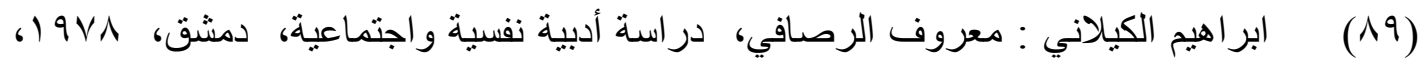

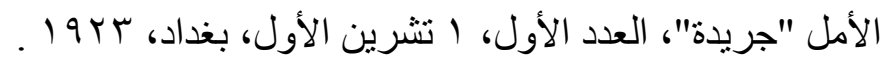

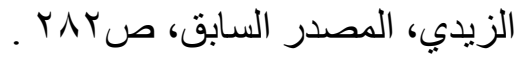

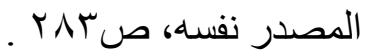

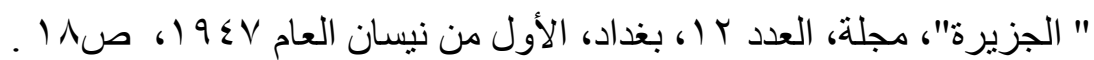

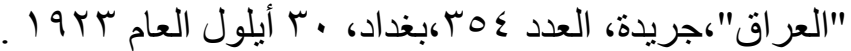

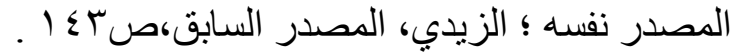

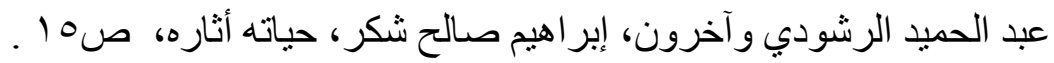

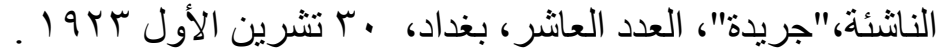

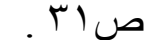

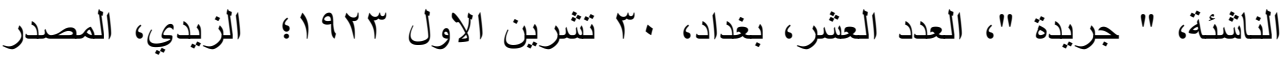




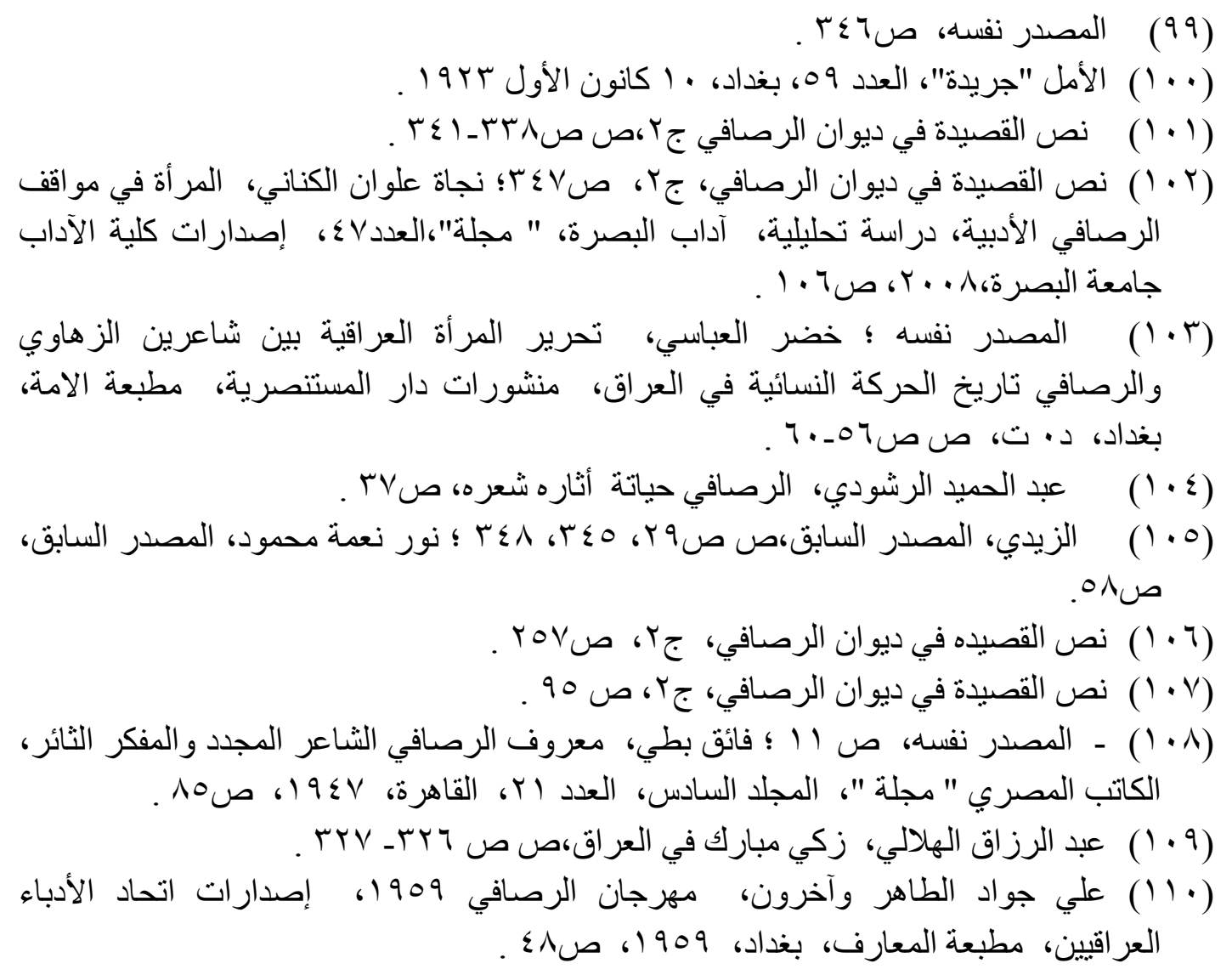

\section{List of sources :}

Theses:

i-Shukri Mahmood Nadeem, the circumstances of Iraq through the stage of the second Mashrotiya 1908-1918, unpublished phd thesis,college of art ,Baghdad university ,1985.

ii-Abdul Razaq Ahmed Al-Nasiri, the role of regeneration in thoughtful and political movement in Iraq 1908-1932, unpublished phd thesis,college of art,Baghdad university, 1990.

iii-Abbas Yasir Al-Zaydi , the history of Iraqi journal since its beginning 1963 , unpublished phd thesis ,college of art, Sun eyes university,cairo 1975.

\section{The Arabization books :}

i- Ibraham Al-Gaylany .Maaroof Al-Resafi ,the social psychological study ,Damascus, 1987.

ii-Ahmed Naji , the linguistics and comment opinions of Al-Resafi, the institute of researches and Arabic study,cairo,1970. 
iii- Ahmed Naji Al-Gurairy and doctor Ekab Yousif Al-Rekaby ,Maroof Al-Resafi (the life and political opinions 1875-1945,Iraqi scientific print ,Baghdad 2011.

iv-Beerdi Fusil, the life of Iraq since 1814-1914, translated Akram Fadhil,Baghdad,1968.

v-Khudhir Al-Abbasi, the freedom of Iraqwoman between twp poets AlZahawi and Al-Resafi, the history of women movement in Iraq, published in Al-Mustansirya housw ,nation print ,Baghdad .

vi- Rafaiel Batti ,poetry magic ,first part, Al-Rahmanya print,Egypt ,1922. vii-Rafaiel Batti ,modern art in Arabic Iraq, first part, Salafism print,Egypt print , 1923.

viii-Raoof Al-Waidh, the national sides in modern Iraqi poetry ,Baghdad,1974.

xi- Shawqi Thayf, studies in contemporary Arabic poetry,Al-Maarif house ,Egypt,1974.

x- Safaa Khalosy ,Maaroof Al-Resafi ,translation by talib Abdul Jabbar AlSamraie ,Baghdad 1953.

xi- Talib Abdul jabbar Al-Samarie ,Maaroof Al-Resafi ,Baghdad D.T.

Abdul Hameed Al-Rashoodi and others ,Ibraham Salih Shukur,life and works.

xii-Abdul Hameed Al-Rashody ,Al-Resafi messages ,Beirut,1994.

xiii-Abdul Kareem Al-Dujaily,lectures about Iraqi modern poetry ,cairo, 1959.

xiv-Ali Jawad AlTahir and others ,Al-Resafi festival 1959,issues of Iraqi writers union,Al-Maarif print ,Baghdad 1959.

xv-Mohib Addin Al-Khateeb , the first Arabic conference, the Sufism print ,Cairo ,1913.

xvi- Mahmood Al-Abta ,Maroof Al-Resafi ,life,worksand situation, cultural affairs house,Baghdad,1992.

xvii-Mustafa Ali,lecturesabout Al-Resafi,Cairo,1954.

xviii-Mustafa Ali ,Maaroof Al-Resafi,connected ,wise, writing, first part, 1984.

xix- prints dictionary, the first part ,Islamic house ,Beirut,1411H. p,.114

Maaroof Al-Resafi, Al-Resafi opinions in religion,politiccs and society,collected and ordered by Saied AlBadry,Baghdad,D.T. 
xx-Maroof Al-Resafi ,Dewan Al-Resafi the second issue, issues of AlAwda house,Beirut,1983.

xxi-Mamdoh Haqi ,Maroof Al-Resafi(analytics and study,Beirut,1964. YosifEzz Addin , thedevelopment of modern thought in Iraq, Asaad print ,Baghdad ,1976.

xxii-Yousif Ezz Addin tells the biography ,Al-mada house print ,Syria 2004.

Personal interviews:

Interview with famous Iraqi historian prof. Dr. Kamal Muthhir Ahmed ,Baghdad 9/August/2009.

\section{Journals:}

i. The new culture (journal), the first no.,Baghdad,1953.

ii. Al-Nibras (journal),no.12,Baghdad, the first of April,1947.

iii. "Al-Jazira"journal ,No.12,Baghdad,the first of April,1947.

iv. Najat Alwan Al-Kenani, the woman in artistic situation of Al-Resafi ,analytic study,Al-Basra Arts,No.47,the issues of college of Basrah ,2008.

v. Faiq Batti, Maaroof Al-Resafi .the renew poet and the thinker ,the Egyptian writer "journal" the 6th issue .No.21,Cairo,1947.

\section{Newspapers :}

i. Iraqi people 'Journal" ,no.187,Baghdad,25thof April,1945.

ii. The guard "journal" ,no.68,Baghdad,13th of March ,Baghdad,1923.

iii. "Al-Iraq" the first issue,1st of October ,Baghdad,1923.

iv. The beginners "journal" the 10th no.,Baghdad,30 of October,1923.

v. The hope "journal" no.59,Baghdad,10of January 1923. 